\title{
Living Outside the Wall: the Quarter of Wattle-and-daub Houses in Old Dongola of the Funj Period
}

\author{
Maciej Wyżgot \\ Polish Centre of Mediterranean Archaeology, University of Warsaw, Nowy Świat St. 4, oo-497 Warsaw, Poland \\ maciej.wyzgol@uw.edu.pl \\ Agata Deptuta \\ Polish Centre of Mediterranean Archaeology, University of Warsaw, Nowy Świat St. 4, oo-497 Warsaw, Poland \\ agata.deptula@uw.edu.pl
}

\begin{abstract}
Excavations at Old Dongola in 2018/2019 led to the discovery of a quarter of wattle-and-daub houses located outside the town walls. The houses, dated to the 17 th-18th century, are arranged in compounds and visibly differ from other dwellings. This paper aims to identify the functional and social organisation of domestic space, based primarily on the analysis of access and activity areas. It sheds light on the relations of private and public space as well as gender divisions. The paper also addresses the question of the identity of dwellers and the social structure of the town in the Funj period.
\end{abstract}

\section{Keywords}

Old Dongola - wattle-and-daub - household archaeology Funj period

\section{Introduction}

\section{Archaeological Context and Historical Setting}

Old Dongola is located on the right bank of the Nile, almost halfway between the Third and the Fourth Cataracts, at the southern edge of the Letti Basin (Godlewski 2013: 7) (Fig. 1). The town was a capital of Makuria until the mid14th century, when the royal court moved to the area of the Second Cataract (Vantini 1975: 699; Żurawski 2014: 86). After the decline of the Kingdom of Makuria, Old Dongola became a capital of a small, local polity - the Kingdom of Dongola. From the 14th century, the town and its vicinity became an important centre of activity of the fugara, teachers of Islam, operating in the Middle Nile Valley (MacMichael 1922: 333). In the 16th century, the Funj period began as Amara Dunqas conquered the former territory of Alwa and founded the Funj Sultanate with its capital in Sennar. Already in the first half of the 16th century, the sultans of Funj dominated Nubia as far north as Dongola, and since the Ottoman Empire had expanded to the Third Cataract, the Kingdom of Dongola became the border zone between the Ottoman and the Funj territories (O'Fahley \& Spaulding 1974: 25-26). The town remained an important political and trade centre until the end of the Funj period (El-Bushra 1971). In the 17th and 18th centuries, separatist tendencies arose in the northern provinces of the Funj Sultanate under the influence of rulers of Querri. Funj power was waning, as in 1659 the dynastic disputes turned into a successful revolt against a ruler of Querri invested by the Funj sultan. In an attempt to reinforce their power over the north, the sultan established a Funj colony encompassing al-Dabba and Korti and appointed the first ruler over Northern Funj, the viceroy manjil Ibrahim (O'Fahley \& Spaulding 1974: 67). The remedy implemented by the sultan turned out to be precarious, the colony diminished and the manjil of Northern Funj was hardly respected by the ruler of Dongola, who, according to Brevedent, was equal to him in power (O'Fahley \& Spaulding 1974: 75). Nonetheless, the rulers of Dongola remained loyal to Sennar until the end of the 18th century, when the insurgent tribe of Shaiqiya devastated Dongola and installed a puppet king (O'Fahley \& Spaulding 1974: 100-101). The end of the Funj Kingdom in the region came with the conquest of Nubia by the forces of Ismail Pasha and abdication of the last sultan of the Funj - Badi VI - in 1821 (Crawford 1951: 275).

Descriptions of Dongola in the Funj period are few. In the $17^{\text {th }}$ and 18th centuries, only the accounts of Evliya Çelebi, Charles Poncet and Theodor Krump describe the 


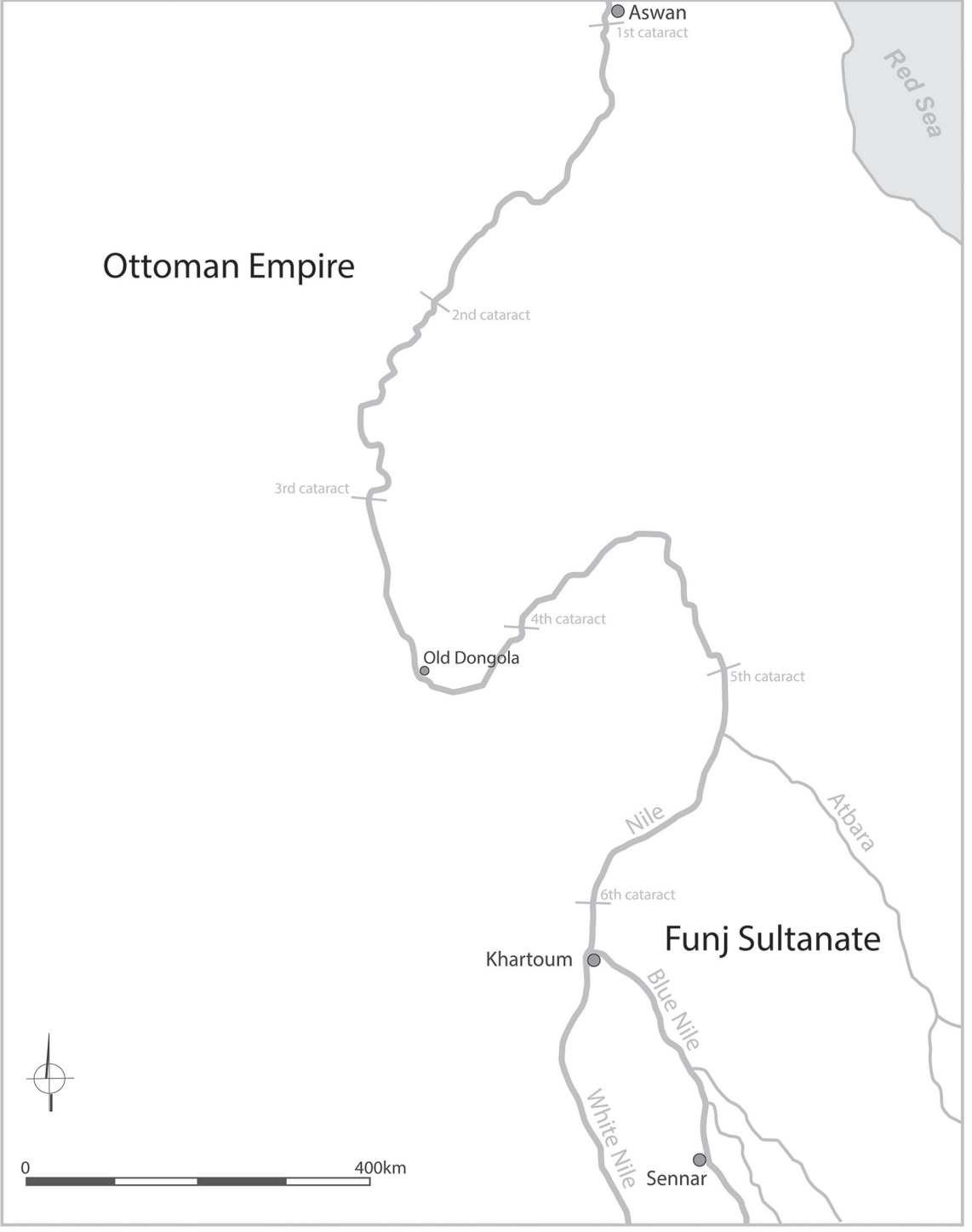

FIGURE 1

Localisation of Old Dongola. DRAWING BY DOBROCHNA ZIELIŃSKA town and its inhabitants. The description recorded by Çelebi is the most detailed, but its reliability is widely questioned due to major discrepancies between his descriptions and the topography of the region south of Qasr Ibrim, as well as numerous passages referring to supernatural phenomena (Peacock 2012: 103-104). Although Çelebi might not have visited Dongola in person, his account should not be altogether dismissed, as it was very likely written on the basis of testimonies of people who had actually visited the town. According to Çelebi (1994: 149-151), Old Dongola in the Funj period was a town with a walled area comprising 650 houses and quarters located outside the walls consisting of 3000 houses. This is also confirmed by Krump, who states that the town was constructed on terraces, each adjoining the one located higher up, and that a fortress was located in the town (Krump 2001: 248). In addition to the number of houses, Çelebi described their construction. The fortress in Dongola mainly had houses made of sun-dried brick, while the settlements outside the walls consisted of houses built either of sun-dried brick, straw, or twigs (Çelebi 1994: 151).

The sources offer little information about the population of Dongola. Nubians living in the Northern Province of the Funj state were generally referred to as Barabra, in contrast to the Funj of the south and to the Arabs. The inhabitants of Dongola were also perceived as being different from the Arabs who, according to Poncet (1709: 14), pastured their livestock in the area in return for a fee paid to the Dongolese. Inhabitants of the town occasionally also suffered from Arab attacks. Çelebi also mentions celabe, tradesmen of Sudanese, Funj and Aswan origin, who lived in the town and formed a group of around a thousand men (Çelebi 1994: 151). 


\section{Project UMMA and New Research on Funj-period Dongola}

Archaeological excavation at Old Dongola started in 1964 and has since been conducted under the auspices of the Polish Centre of Mediterranean Archaeology of the University of Warsaw. In the past, archaeologists focused on Christian monuments from the period when the town was the capital of Makuria, giving only some attention to the late phases associated with post-Makurian and Funj-period occupation (Godlewski 2015a, b; Maślak 2015). A new stage of research began in 2018 with the launch of a European Research Council Starting Grant awarded to Dr. Artur Obłuski for the project "UMMA Urban Metamorphosis of the community of a Medieval African capital city".

UMMA is a multidisciplinary project with the main objective to investigate the liminal phases of a Christian community inhabiting Old Dongola and metamorphosis of the town into a new entity organised along different social and religious paradigms. The project intends to combine methods of inquiry used in disciplines like history, archaeology, geophysics, chemistry, and physics to obtain a multifaceted, cross-disciplinary perspective on the social phenomenon of liminal periods in urbanism.

The period under investigation ranges from the gradual decline of the kingdom of Makuria (the 14th $-15^{\text {th }}$ century) through the formation and functioning of the capital of the Kingdom of Dongola under the influence of the Funj Sultanate (the 16th - early 19th century) until the time when the town was abandoned.

\section{The 2018-2019 Field Season}

During the first fieldwork season of the UMMA project, the main goal was to investigate the latest preserved occupational levels and to expose the urban layout of that period in order to learn more about the everyday life of inhabitants of Old Dongola. The research has revealed living areas both inside and outside the town walls (Fig. 2). The latter area is the main focus of this paper. The residential area inside the enclosure was divided into several quarters by streets running parallel and perpendicular to the town wall. Structures are characterized

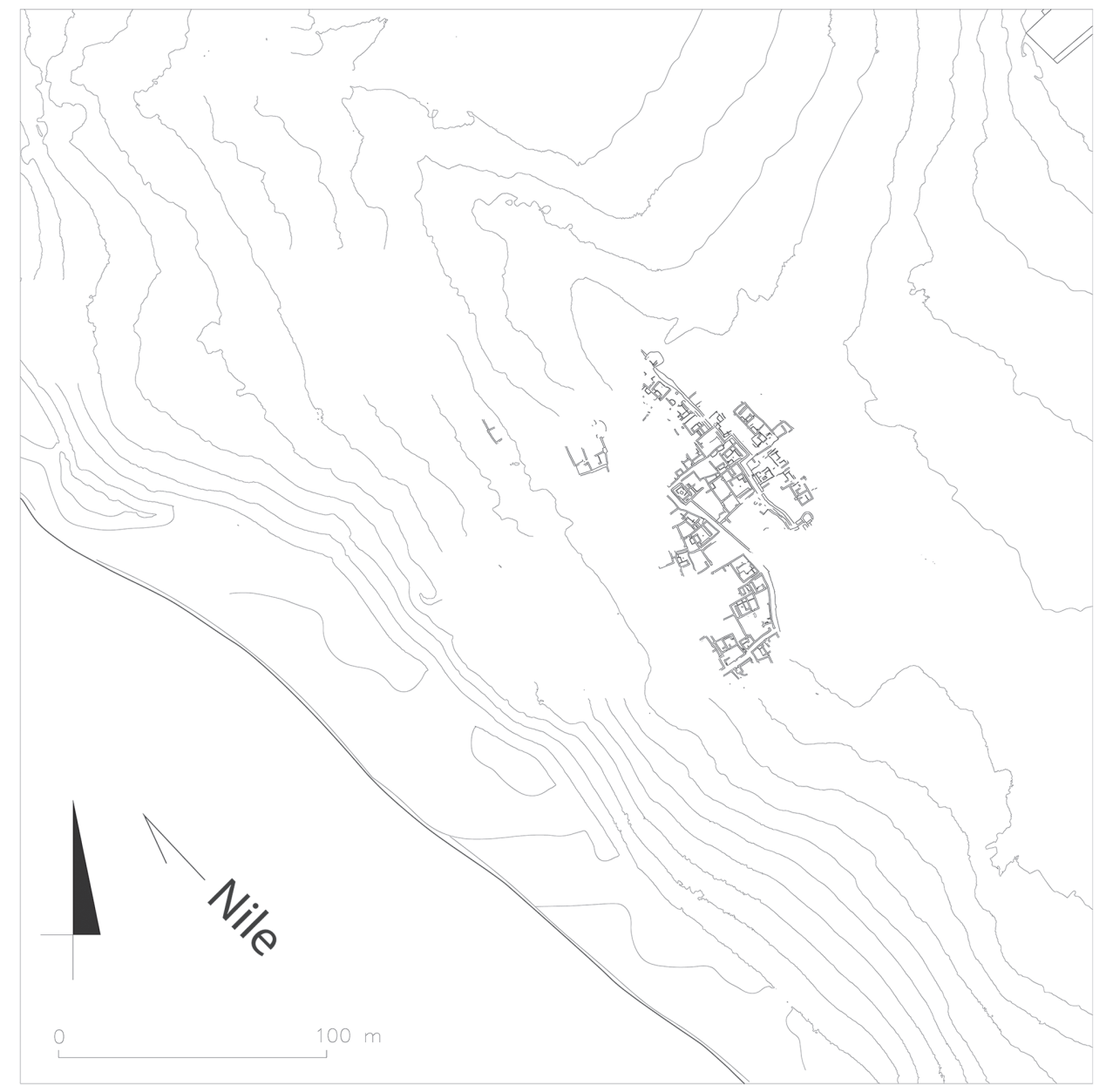

FIGURE 2

Plan of the area excavated in season 2018-2019. DRAWING BY JOANNA SZEWCZYK, AGNIESZKA WUJEC AND ADRIAN CHLEBOWSKI 
by the usage of sun-dried brick as the main building material, and they also share some elements of spatial arrangement (Fig. 3). Generally, although the uncovered households differ in size, shape and number of spaces, they consist of comparable components: a fenced courtyard accessible from the street and several rooms of different purposes. The domestic space was frequently preceded by an entrance passage and its interior was furnished with a number of characteristic elements, like a stub wall screening off the entrance and two or three benches, one of which was invariably located just behind the stub wall. Another recurrent feature was a centrally located stone base for a wooden pillar, which formed part of the construction supporting the roof. The living space was sometimes connected to a long and narrow storeroom through a doorway located in the corner of the room opposite the main entrance. Additional areas with a service and storage function are indicated by the presence of distinctive equipment (storage bins, querns, ovens, etc.). Houses with a similar layout were also discovered in the northern part of Old Dongola, both inside and outside the town walls (Godlewski 2015a, b, 2018), as well as on other sites in the Middle Nile Valley, like Attiri (Adams 1987: 335-336; Osman \&

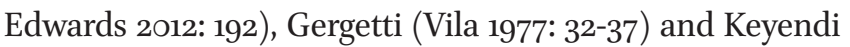
(Vila 1978: 81-85).

\section{Objectives of This Paper}

The aim of this paper is the analysis of the use of space in wattle-and-daub houses in the $17^{\text {th }}$ and 18 th-century Old Dongola. The focus of the investigation is the distribution of certain activities within the houses, as well as the conceptualisation of privacy and gendered areas. An important question to address is also whether this particular technique might have been related to certain economical or environmental conditions or was rather dependent on the building tradition of a particular group of people. This leads to another question concerning the relation of wattle-and-daub architecture to other houses in Old Dongola, which are built of sun-dried brick.

\section{Research Method}

The methods used to process the excavation results discussed herein are inherent to the realm of household archaeology. The term "household archaeology" was first formulated by Richard Wilk and William Rathje in 1982 (Wilk \& Rathje 1982). The subsequent development of methodology, introducing archaeological investigation of houses as an analysis of activity areas (Matthews \& Postgate 1994; Rainville 2005) and investigation of botanical and zoological remains, led to a better understanding of the economic aspects of households. Parallel to these developments, the symbolic dimension of a household as

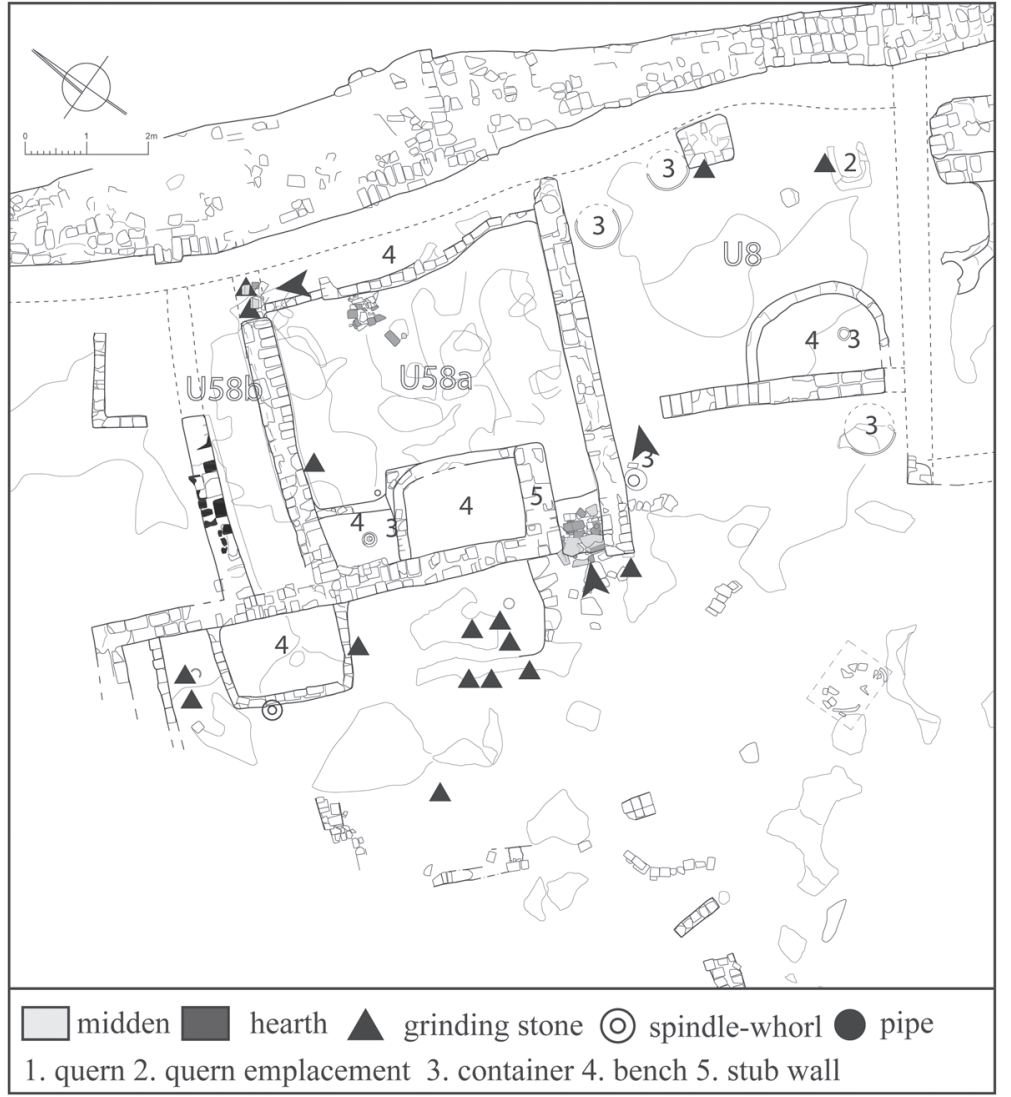

FIGURE 3

Plan of house $\mathrm{U}_{5} 8 \mathrm{a} / \mathrm{U}_{5} 8 \mathrm{~b}$ located within the town walls. DRAWING BY AGNIESZKA WUJEC AND MACIEJ WYŻGOE 
a reflection of social practice was recognised (Bourdieu 1977). The rise of proxemics with its methods, such as access analysis (Hiller \& Hanson 1984), played an important role in understanding the dwellers' perception of domestic space. In recent years, several studies on the relationship of identity and household have appeared, their focus being gender (Nelson 2006), wealth and status (Blanton 1994; Crown 2000), as well as religion (Blier 1987).

Analysis of a house space requires the function of certain areas to be identified, taking into consideration not only the architecture, but also the space as a whole. Since Nubian material culture in the Funj period appears to have been highly portable (Elzein 2004), it is useful to view the house from the perspective of the activities performed. Their analysis is conducted through investigation of the planigraphy of artefacts, distribution of pottery, as well as botanical and faunal remains within the perimeter of the houses or house complexes. The identification of such activity areas, complemented by information about the architecture and of all built-in features, leads to a reconstruction of the function of a space and its changeability.

The methods described above have proved to be useful in the investigation of wattle-and-daub houses of Old Dongola. The dwellers' perception of space within the houses was examined by analysing space syntax. For this purpose, access to particular spaces, as well as visibility and exposure of areas within the house were analysed. This approach gives a better understanding of the conceptualisation of privacy and the public-private dichotomy (Portnoy 1981; Giddens 1984: 122-126). Complementary written sources, namely the accounts of modern-era travellers, contribute to the reconstruction of gender division of labour. As a result, the analysis of accessibility and activity areas may serve as a way to identify gendered spaces and gender relations within households.

The relation of the investigated houses to the rest of the town was based on a careful analysis of building techniques and organisation of space, as well as artefact assemblages in wattle-and-daub houses and their comparison with sun-dried brick houses, taking into account their location within the town. The archaeological data was then compared with written sources describing the town in the 17 th and 18 th centuries.

\section{The Archaeological Record}

\section{Chronology}

The chronology of the excavated sector was established on the basis of a series of radiocarbon dates (Table 2). The samples were collected from structural elements of the houses in order to date the construction of each house.

The radiocarbon dates indicate that the first phase of the wattle-and-daub constructions was built no later than the second quarter of the 17th century, while the latest construction in this area, subsequent to the third phase, was built no later than the end of the 18th century. Stratigraphic relations with earlier structures help to narrow down these dates. A mud brick house preceding phase I, located beneath $U_{15}$, was constructed no earlier than the second half of the 16 th century according to the radiocarbon dates. This places the construction and occupation of the wattle-and-daub houses in the 17th and 18th centuries. Assuming that the lifespan of each house was more or less the same, the most probable dates of each phase are as follows: phase I, turn of 16 th/17th century; phase II, first half of the 17th century; phase III, mid-17th century. Phase III may have lasted until the second half of the 17 th century, when the last recorded structure was erected. Nonetheless, it cannot be ruled out that phase III continued into the 18th century.

\section{Description of the Houses}

The town quarter that comprises the wattle-and-daub houses is located in the area adjacent to the town walls on the north-eastern side. The perimeter walls were so far uncovered along the entire excavated area of the town and were probably still functioning when the houses were built against them, in some cases adopting parts of them as their outer walls. Although the walls certainly divided space into two distinct areas (no gates through them have been identified) the defensive function of the enclosure in the period in question is doubtful. The whole quarter outside the walls is located on a slope ascending towards the walled town. The maximum difference of levels within a simultaneously functioning area (house complex) is estimated to have been o.6 m. On the basis of archaeological data and the accounts of travellers, especially Theodor Krump (2001: 248), it is likely that the dwellings were arranged in terraces along the walls of the town.

The location on the slope and the exposure of the area to northern winds causing erosion of stratigraphic layers and accumulation of aeolian sand hinder the interpretation of the chronological relations between dwelling compounds and between individual houses. Despite these difficulties, it was possible to distinguish three areas of interrelated houses (Fig. 4). Over time (Fig. 5), each of them underwent several changes in arrangement, marked by the construction of new houses within a compound or by refurbishment of the already existing structures. 
TABLE 1 Details of the construction and the furnishing of the houses

House Room Phase Elev. Size Roof Walls Doorway

\begin{tabular}{|c|c|c|c|c|c|}
\hline 21 & $21 a$ & I & 19.15 & $9.5 \mathrm{~m}^{2}$ & $\begin{array}{l}\text { Presumed, no } \\
\text { evidence }\end{array}$ \\
\hline & $21 b$ & II & 19.26 & $12.2 \mathrm{~m}^{2}$ & $\begin{array}{l}\text { Presumed, no } \\
\text { evidence }\end{array}$ \\
\hline 28 & $28 \mathrm{a}$ & I & 19.45 & $5 \mathrm{~m}^{2}$ & $\begin{array}{l}\text { Presumed, no } \\
\text { evidence }\end{array}$ \\
\hline
\end{tabular}

II $\quad 19.78$

28b I-II $\quad 19.69 \quad 13.85 \mathrm{~m}^{2} \quad$ Supported by a pillar standing on a pillar base made of stone

\begin{tabular}{|c|c|c|c|c|c|}
\hline \multirow[t]{2}{*}{29} & \multirow[t]{2}{*}{29} & II & $\begin{array}{l}20.18- \\
20.28\end{array}$ & $12 \mathrm{~m}^{2}$ & \multirow[t]{2}{*}{$\begin{array}{l}\text { Presumed, no } \\
\text { evidence }\end{array}$} \\
\hline & & III & 20.50 & & \\
\hline \multirow[t]{2}{*}{47} & $47^{a}$ & I & 19.20 & $>8.5 \mathrm{~m}^{2}$ & $\begin{array}{l}\text { Presumed, no } \\
\text { evidence }\end{array}$ \\
\hline & $47 \mathrm{~b}$ & I & $19 \cdot 30$ & $16 \mathrm{~m}^{2}$ & $\begin{array}{l}\text { Postholes } \\
\text { left by pillars } \\
\text { supporting } \\
\text { roof }\end{array}$ \\
\hline
\end{tabular}

Sun-dried brick covered with whitewashed plaster, wattle-anddaub construction attached to its western part (S); wattle-and-daub covered with whitewashed plaster $(\mathrm{W}, \mathrm{N})$; wattle-and-daub with stone footing (E)

Wattle-and-doub covered with whitewashed plaster (N, W, S), wattle-and-daub with stoone footing

Attached to the sun-dried brick curtain wall covered with seceral layers of whitewashed plaster within the unit (W); sun-dried brick covered with plaster $(\mathrm{N})$; wattle-and-daub covered with several layers of whitewashed plaster (S, E)

Additional layer of whitewashed plaster (W, S)

Wattle-and-daub (W, N, E); wattle-and-daub covered with several layers of whitewashed plaster (S)

Attached to the sun-dried brick curtain walls $(\mathrm{N}, \mathrm{W})$; wall made of re-used fragments of brick, wattle-and-daub construction attached to its southern parts (S); wattle-and-daub covered with plaster (S)

Wattle-and-daub (N, S); eastern and western walls not preserved Sun-dried brick covered with plaser, wattle-and-daub construction attached to its western part $(\mathrm{N})$; wattle-and-daub (E, S); western wall not preserved
Threshold made of baked brick located in SW corner, negative of a door pivot; semicircular threshold made of sun-dried brick in NW corner

Baked brick with negative of door pivot

Sun-dried brick threshold covered with whitewashed plaster located in NW corner; gateway in SE corner, structure not preserved

Threshold in NW corner raised by adding two stone slabs; treshold made of baked brick covered with whitewashed plaster in SE corner Threshold made of baked brick covered with whitewashed plaster in SW corner

\section{Presumed, no evidence}

Sun-dried brick threshold overlaying curtain wall in NE corner Presumed, no evidence

Presumed, no evidence 


\begin{tabular}{|c|c|c|c|c|c|}
\hline Stub Wall & Benches & Floor & Access & Hearth & $\begin{array}{l}\text { Additional } \\
\text { equipment }\end{array}$ \\
\hline
\end{tabular}

$\begin{array}{llll}\text { No } & \begin{array}{l}\text { L-shaped bench with } \\ \text { sun-dried brick casing } \\ \text { against N and E walls }\end{array} & \begin{array}{l}\text { Mud pavement } \\ \text { with traces of } \\ \text { whitewashing }\end{array} & \begin{array}{l}\text { From the } \\ \text { courtyard }\end{array}\end{array} \quad \begin{aligned} & \text { Round burnt spots in } \\ & \text { the middle of the room }\end{aligned}$
Storage vessel made of baked clay embedded in a bench

\begin{tabular}{|c|c|c|c|c|}
\hline No & $\begin{array}{l}\text { Two small benches with } \\
\text { sun-dried brick casing } \\
\text { against } \mathrm{N} \text { and } \mathrm{E} \text { wall }\end{array}$ & Mud & $\begin{array}{l}\text { From the } \\
\text { room U21a }\end{array}$ & $\begin{array}{l}\text { Round burnt spots in } \\
\text { the middle of the room; } \\
\text { accumulation of ashes } \\
\text { in NE corner }\end{array}$ \\
\hline No & No & $\begin{array}{l}\text { Thick mud pave- } \\
\text { ment with traces of } \\
\text { whitewashing }\end{array}$ & $\begin{array}{l}\text { From the } \\
\text { courtyard }\end{array}$ & No \\
\hline
\end{tabular}

Thin mud pavement with traces of whitewashing

\section{Thick mud}

pavement with trac-

From the

U28a

es of whitewashing

small bench with sun-dried

brick casing against $\mathrm{N}$ wall

No

Presumed against $\mathrm{N}$ wall

Sun-dried brick

wall

No

No

Wall made of different types Two benches against $\mathrm{W}$ and E walls

\section{At least three layers Not clear}

of tamped midden

\author{
Three small, oval \\ hearths overlaying \\ upper surface of small \\ bench; layer of ashes \\ against small bench
} Accumulation of ashes No in NW corner

of bricks and

stones

$\begin{array}{lllc}\begin{array}{l}\text { At least two layers of } \\ \text { tamped midden }\end{array} & \begin{array}{l}\text { From court- } \\ \text { yard (?) }\end{array} & \text { N/A } & \text { No } \\ \begin{array}{l}\text { Pavement made of } \\ \text { tamped midden }\end{array} & \begin{array}{l}\text { From court- } \\ \text { yard (?) }\end{array} & \text { N/A } & \text { No } \\ \begin{array}{l}\text { Presumed, no } \\ \text { evidence }\end{array} & \begin{array}{l}\text { From the } \\ \text { room U47a }\end{array} & \text { N/A } & \text { No }\end{array}$


TABLE 1 Details of the construction and the furnishing of the houses (cont.)

House Room Phase Elev. Size Roof Walls

\begin{tabular}{|c|c|c|c|c|c|}
\hline 36 & 36 & III & $\begin{array}{l}20.06- \\
20.41\end{array}$ & $>11.2 \mathrm{~m}^{2}$ & $\begin{array}{l}\text { Presumed, no } \\
\text { evidence }\end{array}$ \\
\hline \multirow[t]{2}{*}{20} & $20 \mathrm{a}$ & II & $\begin{array}{l}19.96- \\
20.06\end{array}$ & $13.7 \mathrm{~m}^{2}$ & $\begin{array}{l}\text { Presumed, no } \\
\text { evidence }\end{array}$ \\
\hline & $2 \mathrm{ob}$ & II & 19.93 & $>2.9 \mathrm{~m}^{2}$ & $\begin{array}{l}\text { Presumed, no } \\
\text { evidence }\end{array}$ \\
\hline 27 & 27 & III & $\begin{array}{l}20.46- \\
20.53\end{array}$ & $>15.6 \mathrm{~m}^{2}$ & $\begin{array}{l}\text { Presumed, no } \\
\text { evidence }\end{array}$ \\
\hline 37 & 15 & II & $\begin{array}{l}19.30 \\
\text { (up to } \\
19.70 \text { ) }\end{array}$ & $21.2 \mathrm{~m}^{2}$ & $\begin{array}{l}\text { Presumed, } \\
\text { wooden pillars }\end{array}$ \\
\hline
\end{tabular}

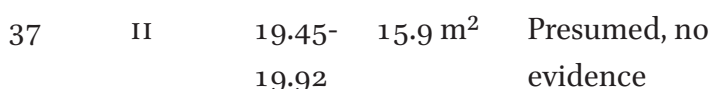

Sun-dried brick wall (N); not
preserved (E); wattle-and-daub,
mud plastered and whitewashed

(S); sun-dried brick wall (S)

Wattle-and-daub, mud plastered and whitewashed $(\mathrm{N})$; wattle-anddaub, mud plastered and whitewashed (E); wattle-and-daub, mud plastered and whitewashed (S); stone blocks, reused wall, mud plastered

Wattle-and-daub, mud plastered, whitewashed $(\mathrm{N})$; wattle-anddaub mud, mud plastered, whitewashed; wattle-and-daub, mud plastered, whitewashed (S); E wall is not preserved

Wattle-and-daub, mud plastered, N/A whitewashed $(\mathrm{N})$; sun-dried brick, baked bricks and stones, mud plastered and whitewashed (S); sun-dried brick, baked bricks and stones, mud plastered and whitewashed (W); E wall is not preserved Sun-dried brick, mud plastered, Reopened blocking wall in the E whitewashed $(\mathrm{N})$; sun-dried brick, wall, wooden threshold added in mud plastered, whitewashed (E); the later phase sun-dried brick, mud plastered, whitewashed (S); sun-dried brick, mud plastered, whitewashed (W) Wattle-and-daub, mud plasterd, whitewashed $(\mathrm{N})$; wattle-anddaub, mud plastered, whitewashed (E); wattle-and-daub, mud plastered, whitewashed (S); wattle-and-daub, mud plastered, whitewashed attached to a sundried brick wall, mud plastered, whitewashed (W)
Stone slab with a traces of a pivot in the $\mathrm{N}$ wall

Stone slab with a traces of a pivot in the $\mathrm{N}$ wall
N/A 


\begin{tabular}{|c|c|c|c|c|c|}
\hline Stub Wall & Benches & Floor & Access & Hearth & $\begin{array}{l}\text { Additional } \\
\text { equipment }\end{array}$ \\
\hline $\mathrm{N} / \mathrm{A}$ & $\begin{array}{l}\text { Sun-dried brick bench in } \\
\text { the NE corner }\end{array}$ & $\begin{array}{l}\text { Several thin layers of } \\
\text { tamped mud }\end{array}$ & $\begin{array}{l}\text { From the } \\
\text { room } 20 \mathrm{~b}\end{array}$ & $\begin{array}{l}\text { A hearth located in the } \\
\text { middle of the room }\end{array}$ & No \\
\hline
\end{tabular}

$\begin{array}{lll}\text { N/A } & \begin{array}{l}\text { Sun-dried brick bench in } \\ \text { the eastern part }\end{array} & \begin{array}{l}\text { Several thin layers of } \\ \text { tamped mud }\end{array}\end{array} \quad$ N/A N $\quad$ N/A
N/A
Segmented, presumbly
Tamped mud
N/A
A hearth located in the
$\mathrm{N} / \mathrm{A}$
L-shaped bench in the
E part; oblong sun-dried
corner of the benches
brick bench in the $\mathrm{S}$ part

No

No

L-shaped sun-dried brick bench in the NE corner,

brick wall,

mud plastered,

whitewashed

attached to the stub wall
Several thin layers of

tamped mud
From the

courtyard
A hearth located in the
SE corner
A mud container

located in the central part of the room; quern emplacement located by the $\mathrm{S}$ wall

No 
TABLE 2 Chronology of the excavated area on the basis of the radiocarbon dating

\begin{tabular}{|c|c|c|c|}
\hline Description & Phase & $\begin{array}{l}\text { Most probable } \\
\text { interval within } \\
95.4 \% \text { certainty }\end{array}$ & Probable date \\
\hline $\mathrm{U}_{21}$ & I & $1484-1648$ & $\begin{array}{l}\text { Turn of } \\
16 \text { th/1 } / \text { th } c ?\end{array}$ \\
\hline $\mathrm{U}_{2} 8$ & I & $\begin{array}{l}1458-1531(41.3 \%) \\
1539-1635(54.1 \%)\end{array}$ & $\begin{array}{l}\text { Turn of } \\
16 \text { th/1 } 7_{\text {th }} \mathrm{c} ?\end{array}$ \\
\hline $\mathrm{U}_{37}$ & II & $\begin{array}{l}145^{0-1530}\left(47 \cdot 7^{\circ} \%\right) \\
1540-1635\left(47 \cdot 7^{\%}\right)\end{array}$ & $\begin{array}{l}\text { I half of } 17^{\text {th }} \mathrm{c} \text { or } \\
\text { earlier (old wood } \\
\text { effect) }\end{array}$ \\
\hline $\mathrm{U}_{15}$ & II & $1477-1643$ & $\begin{array}{l}\text { I half of } 17^{\text {th }} \mathrm{c} \text { or } \\
\text { earlier (old wood } \\
\text { effect) }\end{array}$ \\
\hline $\mathrm{U}_{29}$ & II & $\begin{array}{l}1514-1600(49 \%) \\
1616-1668(42.4 \%) \\
1782-1798(4 \%)\end{array}$ & I half of $17^{\text {th }} \mathrm{c}$. \\
\hline $\mathrm{U}_{20} \mathrm{O}$ & II & $\begin{array}{l}1521-1592(21.5 \%) \\
1620-1675(54.9 \%) \\
1777-1800(16.2 \%) \\
1941-\ldots(2.7 \%)\end{array}$ & I half of $17^{\text {th }} \mathrm{c}$. \\
\hline $\mathrm{U}_{3} 6$ & III & $\begin{array}{l}1530-1539(0.9 \%) \\
1635^{-1684}(44.7 \%) \\
1736-1805(39.2 \%) \\
1935^{-\ldots}(10.6 \%)\end{array}$ & mid $17^{\text {th }} \mathrm{c}$. \\
\hline $\begin{array}{l}\text { Last } \\
\text { construction }\end{array}$ & $\begin{array}{l}\text { After } \\
\text { III }\end{array}$ & $\begin{array}{l}1520-1593(28.3 \%) \\
1619-1670(53.1 \%) \\
1780-1800(12.3 \%) \\
1943^{-\ldots}(1.6 \%)\end{array}$ & II half of $17^{\text {th }} \mathrm{c}$. \\
\hline
\end{tabular}

Area A is located in the south-eastern part of the quarter. It was excavated to the earliest phase recorded so far, not reached in other areas of the town quarter under consideration. It functioned until the last phase of occupation recorded in this part of the town.

Area B is located in the central part of the quarter. It was excavated to a level following the earliest phase recorded in area A. It consisted of only one house, related either to the houses in area A or in area C.

Area $\mathrm{C}$ is located in the north-western part of the quarter. The houses in this part are poorly preserved, but it is possible to determine that the last phase exposed there comprised the latest houses in the district. The area was excavated to a level contemporary to the house in area B.

The individual houses shared domestic workspaces, middens and animal pens, and should therefore be considered as units with common spaces located in their

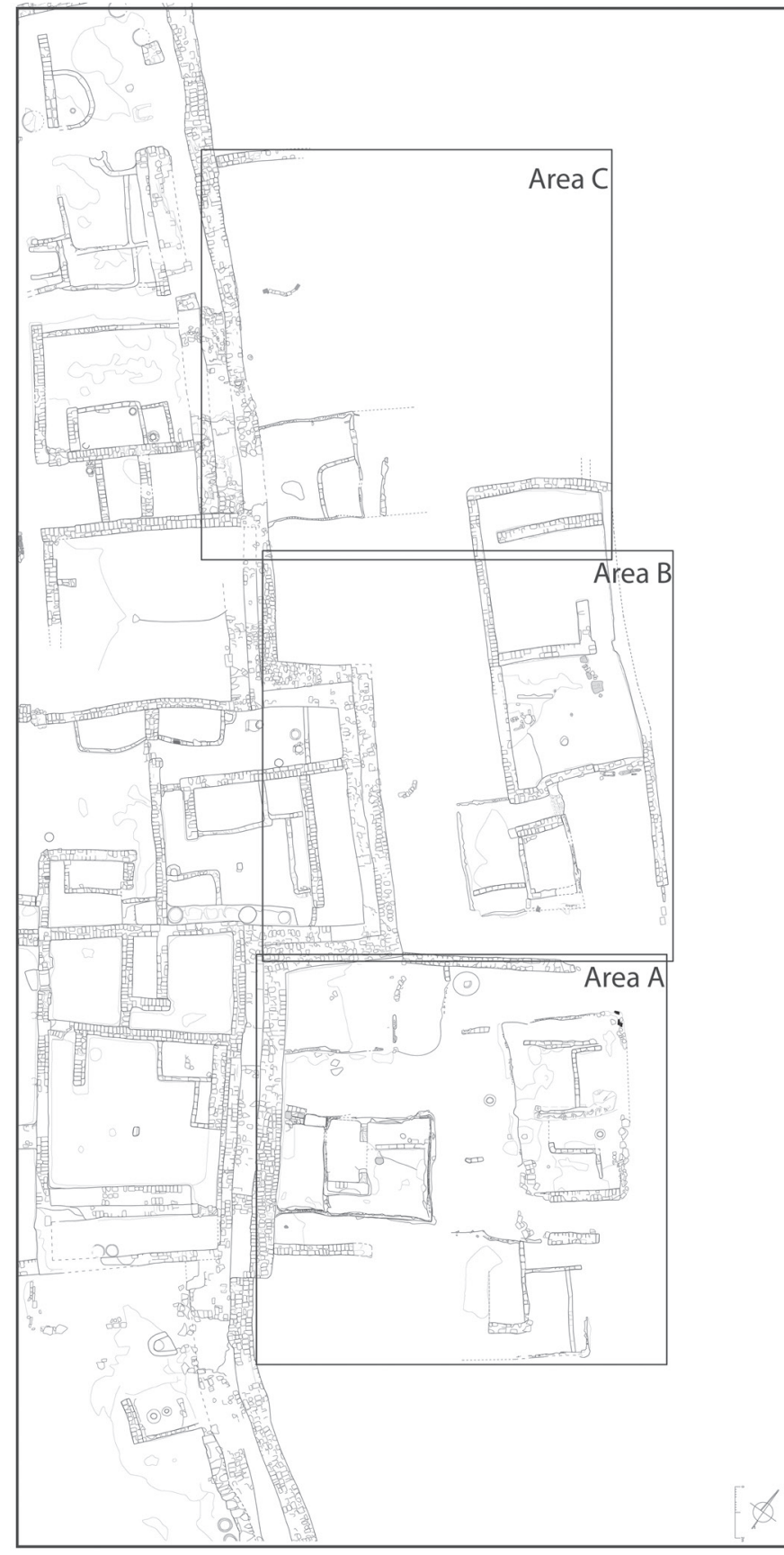

FIGURE 4 The areas A, B and C. DRAWING BY AGNIESZKA WUJEC

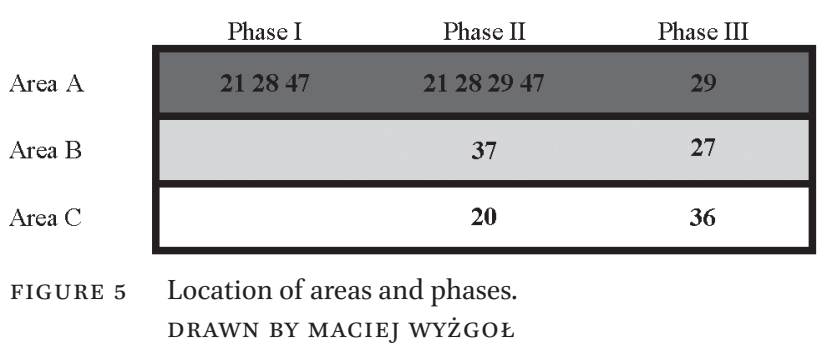




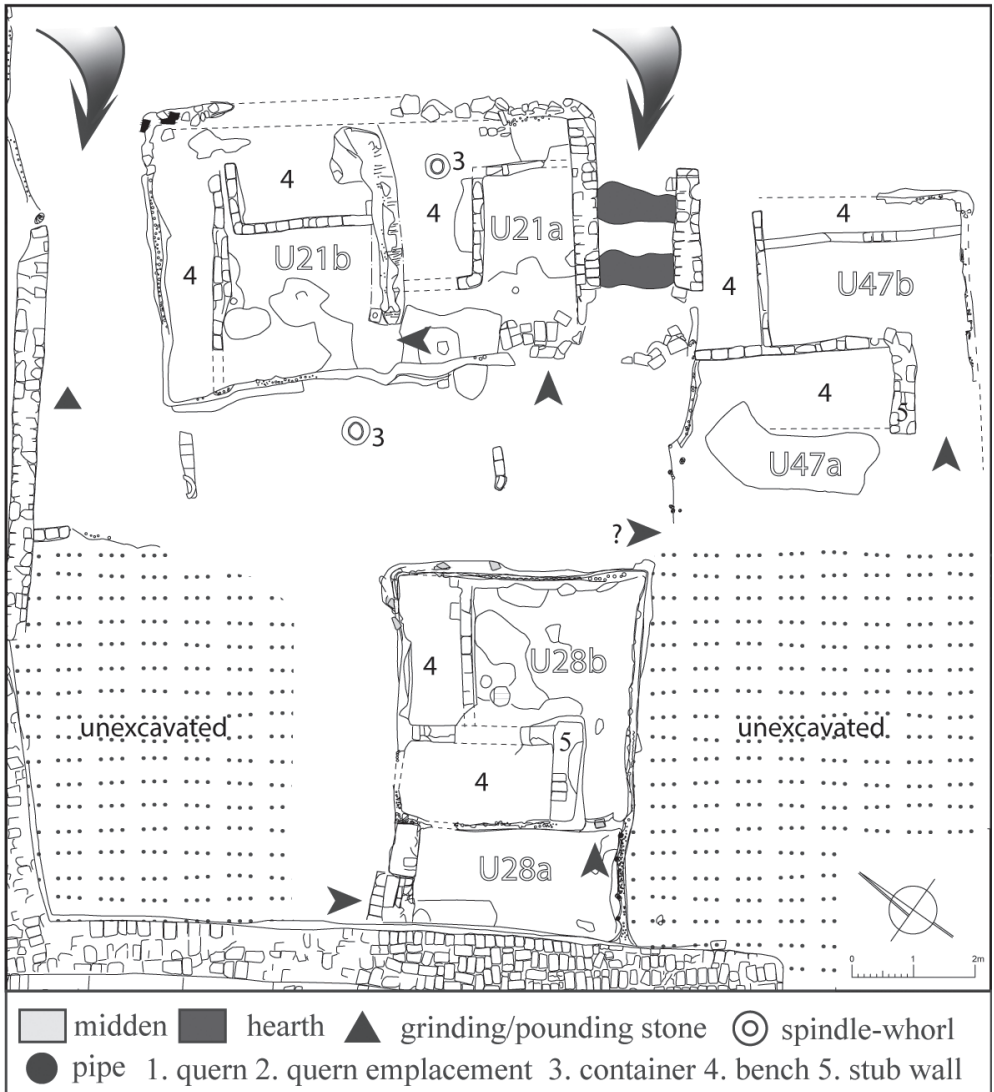

FIGURE 6

Plan of the area $\mathrm{A}$ in the 1st phase.

DRAWING BY AGNIESZKA WUJEC AND AGATA DEPTUŁA vicinity. For this reason, they are described as compounds wherever they are identifiable as such. Where it has proved impossible to trace the relations between the houses, they are described separately, with indication of their presumed domestic workspace. ${ }^{1}$

The construction methods employed in all three areas are varieties of the wattle-and-daub technique. The framework of the wattle always consists of vertical elements set in a foundation of Nile silt. They are typically branches ca. 4-6 cm thick, set 40-6o cm apart, and the space between them is filled with vertically placed twigs or reeds. The vertical elements are interlaced with horizontal twigs or reeds. The latticework is covered with Nile mud mortar and, in some cases, coated on both sides with smoothed brownish-yellow desert clay and whitewashed with desert kaolinite clay. The wattle-and-daub houses were usually built up against earlier, sturdier structures like town walls or had at least one load-bearing wall made of sun-dried brick (for detailed information concerning wall construction of each house, see Table 1).

\section{Area A}

Area A was separated from the more northerly areas by a wall, which most probably predated the other structures

1 Details of construction and furnishing are listed in Table 1. and was originally part of an earlier occupational phase. The southern and eastern boundaries of this area have not been identified. In the part we investigated, four wattleand-daub houses were unearthed, three of them contemporary (houses U21a/21b, U28a/28b and $U_{47} a / 47 b$ ), and one (house U29) added later.

The three oldest recorded dwellings (Fig. 6) were built on an unstable surface of aeolian sand. The house U21a/21b comprised two spaces connected by a passageway that could be closed off with a door. Both spaces were equipped with benches which occupied most of the space. Since there are no signs of refurbishment, it seems that the house had only one occupational phase. Most walls collapsed after abandonment, forming compact layers of debris. Later, the whole structure was covered with aeolian sand. Samples collected within both spaces contained significant amounts of sorghum grains and spikelets and some content of colocynth seeds, as well as remains of acacia. ${ }^{2}$

House U28a/28b, which abutted the town wall, is the best-preserved building of the area. In its layout it is comparable to dwellings situated on the other side of the town

2 All information concerning organic remains was provided by Mennat Allah el-Dorry in the unpublished report: Old Dongola. Fieldwork in 2018-2019 season. 
enclosure walls (Fig. 3). It consists of two rooms: the small and narrow $\mathrm{U}_{28} 8$ a, serving as a kind of vestibule, and the large U28b. The layout of the main room was typical for houses of the Funj period excavated in Old Dongola thus far. The doorway opened onto a narrow corridor flanked by a sun-dried brick stub wall that screened off a large bench. The whole surface was covered with a mud floor overlapping a centrally located round stone base for a pillar, which served as a roof support.

House U47a/47b most probably had a similar spatial arrangement, with an entrance vestibule ( $\left.\mathrm{U}_{47} \mathrm{a}\right)$ and a main room furnished with benches $\left(\mathrm{U}_{47} \mathrm{~b}\right)$. Especially worthy of interest are two large post-holes visible in the construction of the sun-dried brick walls, probably left by pillars supporting the roofing. Most of the features of this building are severely damaged, thus it is impossible to draw any conclusions concerning its occupational phases.

The aforementioned houses were accessible from a common, centrally located courtyard. The courtyard most likely extended to the town walls, but in this part it remains uninvestigated. Most of this area was subject to post-depositional wind erosion, leaving preserved occupational layers only in a small area between houses $\mathrm{U}_{28} \mathrm{a} / 28 \mathrm{~b}$ and $\mathrm{U}_{29}$ and against enclosing walls. The central part was filled with a massive layer of aeolian sand reaching a thickness of more than $1 \mathrm{~m}$. The only preserved features were a vessel of baked clay set in the surface and two hearths located on the edges of the courtyard, sheltered with small sun-dried brick screen walls.

Later rearrangements are visible only inside house $\mathrm{U} 28 \mathrm{a} / 28 \mathrm{~b}$ and in its vicinity. In space U28a, another floor was laid c. $10 \mathrm{~cm}$ above the original one. Concurrently, the western face of the curtain wall inside the house was coated with an additional layer of plaster and the threshold was raised to match the floor level. Parallel to the development inside the house, the walking level outside was naturally elevated and the wall delimiting the space from the west was covered with the first layer of plaster. From the south, the area was delimited with a new sun-dried brick wall forming a narrow semi-open space adjacent to house $\mathrm{U}_{28} \mathrm{a} / 28 \mathrm{~b}$. Its surface was covered with a layer of tamped refuse.

At approximately the same time, building U29 was added in the corner of the town walls (Figs. 7,8 ). The building comprised only one space with no traces of furnishings. The only distinctive features are the consecutive floor layers made of tamped refuse with a substantial admixture of ashes and an abundant accumulation of ashes in the corner of the building. It is not clear where the original entrance to the building was located. A threshold connected with the latest phase overlay the town wall that delimited the house from the north. This implies that

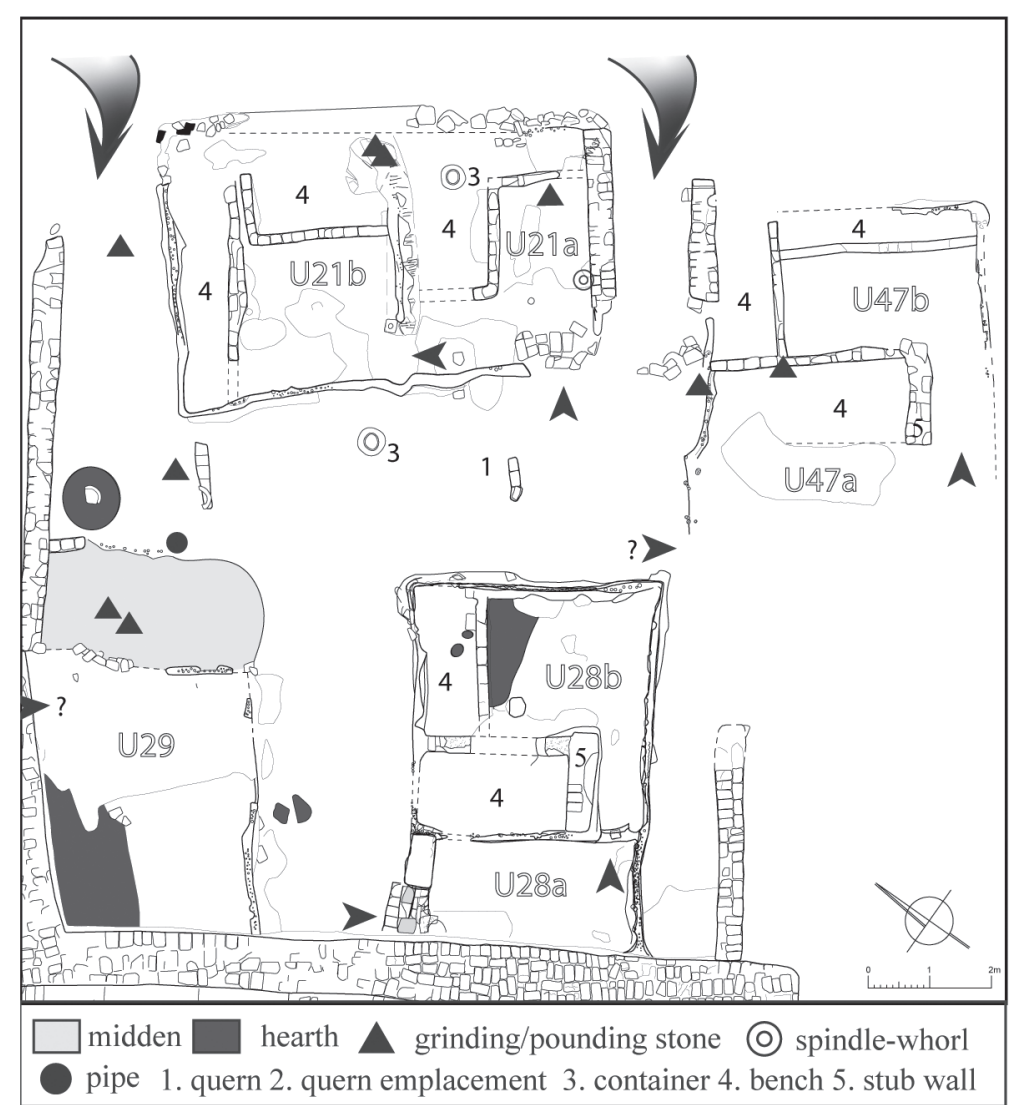

FIGURE 7

Plan of the area A in the 2nd phase. DRAWING BY AGNIESZKA WUJEC AND AGATA DEPTUŁA 


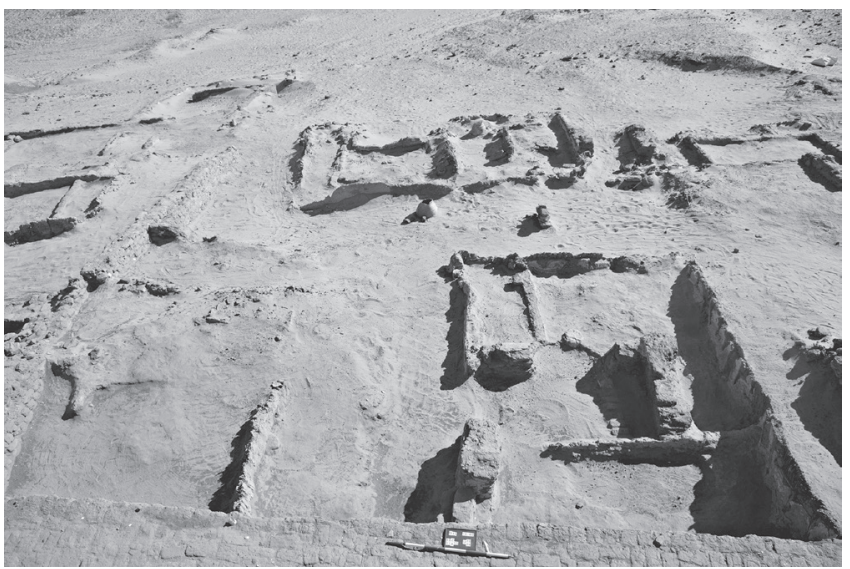

FIGURE 8 Houses in the area A during the 2nd phase. PHOTOGRAPH BY MATEUSZ REKŁAJTIS

in the terminal period of use this space was connected with the area located in the central and north-western part of the quarter (as well as with the houses $\mathrm{U}_{27}$ and $\mathrm{U}_{36}$ ). At this stage, a new sun-dried brick wall was added next to the entrance, perhaps as a screen wall of a hearth. Subsequently, additional layers of consecutive floors of tamped refuse were laid, the uppermost of which bears oval impressions probably left by pots placed on the surface.

In the latest occupational phase, house $\mathrm{U}_{2} 8 \mathrm{a} / 28 \mathrm{~b}$ was filled with a layer of debris comprising fragments of mud mortar with some pieces covered with white plaster, possibly elements of walls. The entire layer was levelled and tamped.

\section{Interpretation}

In the earliest occupational phase, houses U21a/21b, $\mathrm{U} 28 \mathrm{a} / 28 \mathrm{~b}$ and $\mathrm{U}_{47 \mathrm{a}} / \mathrm{b}$ most probably constituted a single compound. The houses primarily served as living quarters, as is indicated by the presence of benches. In most cases the interiors bear no clear evidence of areas connected with food processing or storing, although due to the poor state of preservation of the structures other functions cannot be definitely excluded. Only a relatively small vessel embedded in a bench inside U21a and the presence of sorghum remains in a layer above floor level suggest that food might have been kept, processed or consumed within the house. Small, round burnt spots visible on the floor within this house were more likely left by a censer or lamp than by a hearth.

Most of the daily activities must have been performed outside, in the courtyard, which was located in the central area between the three buildings and thus played the role of a common space for all of them. The earliest recognised space connected with food preparation was situated in the narrow passageway between houses U21a/21b and
$\mathrm{U}_{47 \mathrm{a}} / 47 \mathrm{~b}$, as is indicated by a layer of ash and burnt matter accumulated on the surface. It was closed off from the east by a curved sun-dried brick screen wall, but no other structures were attached. Another, most probably later hearth was located north of house U21a/21b. A fragment of a cooking pot discovered in situ, as well as organic inclusions (comprising wheat and sorghum grains) within the hearth deposit revealed that this space was also certainly associated with food processing.

It is often presumed that a courtyard should also include pens for keeping livestock, usually sheltered with perishable material and therefore attested primarily by dung deposits. Within area $\mathrm{A}$, animal faeces are present only as an admixture of fragmented inclusions in the occupational deposits. Keeping animals is indicated only by the presence of completely preserved chicken eggs (Fig. 9) discovered on a layer of sand serving as a walking level in this space.

The only feature that might be connected with food storage was a relatively small vessel made of baked clay with an opening cut in the lower part, intended for keeping grain, which was located in the central part of the courtyard.

It is impossible to determine whether houses U21a/21b and $U_{47} \mathrm{a} / 47 \mathrm{~b}$ were still in use when $\mathrm{U}_{29}$ was constructed. Due to erosion caused by wind during the postdepositional phase, there is a scarcity of occupational layers both inside the house $\mathrm{U}_{47} \mathrm{a} / 47 \mathrm{~b}$ and above the accumulation of debris from collapsed walls covering both structures.

During a later phase, cooking may have taken place inside $\mathrm{U}_{2} 8 \mathrm{~b}$, as indicated by an accumulation of ashes along a small bench and by traces of three minor hearths

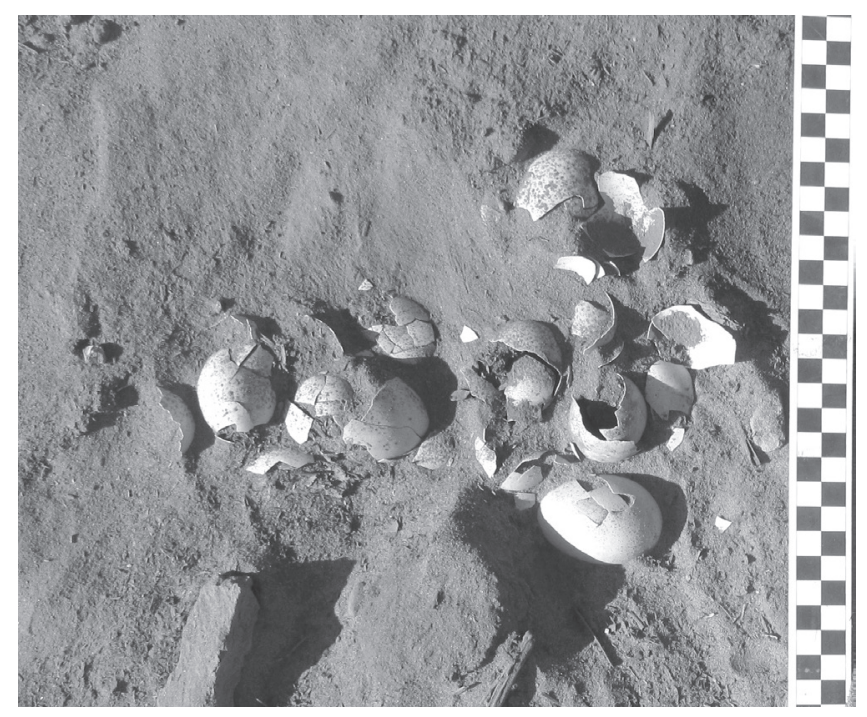

FIGURE 9 Chicken eggs unearthed in the area A. PHOTOGRAPH BY AGATA DEPTUŁA 
in a place originally occupied by a mortar coating on the upper surface of the bench. Isolated hearths are also visible in the space between $U_{2} 8 \mathrm{a} / 28 \mathrm{~b}$ and U29. The narrow space established during this period between $\mathrm{U}_{28} \mathrm{a} / 28 \mathrm{~b}$ and the wall delimiting the area may have been used for storage. It corresponds in terms of size, form, and location with parallel spaces known from compounds excavated within the town walls. This supposition can be additionally confirmed by numerous impressions of reeds and plaited mats preserved on the surface and a variety of archaeobotanical remains including sorghum, barley, foxtail millet, colocynth, and flax.

Undoubtedly the main area connected with food processing was U29, which bears no traces of other activities. The intensity of use of this space is indicated by the successive layers of tamped refuse mixed with ashes, serving as a walking surface. Another question is whether this space was in the last phase related to area $\mathrm{A}$, or if it was rather related to the houses in areas $\mathrm{B}$ and $\mathrm{C}$.

In the terminal phase, traces of intensive occupation are visible only inside space U29. A thick layer of ashes and impressions of pots indicate clearly that the space was still connected with food processing. The rest of the area under consideration remained uninhabited and formed an open and easily accessible space sheltered by the town wall. Part of the walking and working level was constituted by tamped and levelled layers of debris from the collapsed walls of U28a/28b (Fig. 10). No structures are preserved, nor are there artefacts indicating any specific activity that took place within this area. Still, it may be assumed that the area remained a place of sporadic human activity as indicated by the accumulation of anthropogenic deposits interspersed with isolated bonfires and small finds, amongst which a magical ostracon (inv. no. 44) with Arabic inscriptions on both sides is especially remarkable.

The organisation of space in the south-eastern area is best recognised in the period when all three dwellings were in use simultaneously. A compound with several spaces intended for living and sleeping could have been inhabited by an extended family. It constituted an isolated space with a private inner courtyard accessible from the outside through narrow passageways between the buildings, though without traces of doors restricting access. One cannot exclude also the possibility of the existence of another, external courtyard in the area, not fully recognized so far. Such a space could have been located east of the living compound and would have been connected directly with the public space of the town, forming the area for interaction with non-family-members and enhancing the privacy of the part intended for daily domestic use.

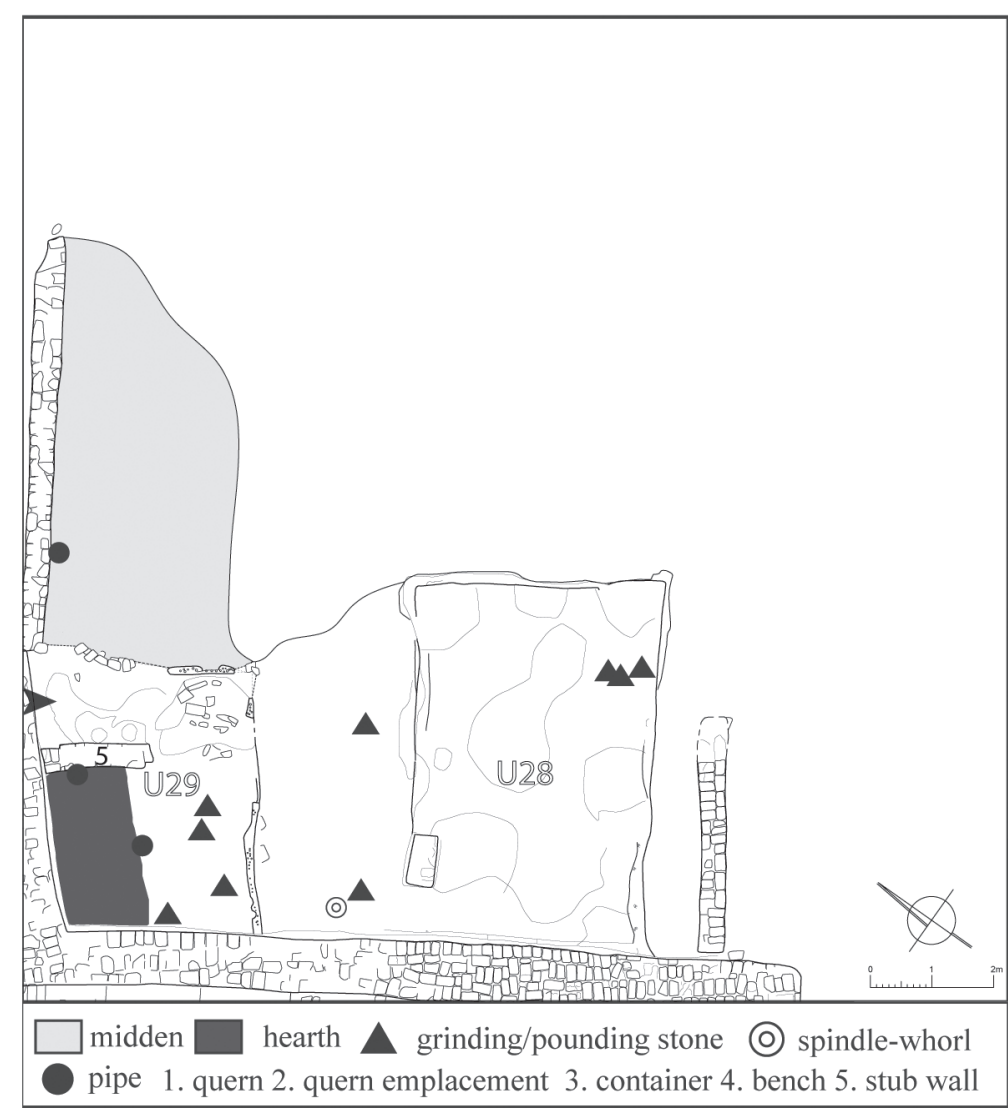

FIGURE 10

Plan of the area A in the 3 rd phase.

DRAWING BY AGNIESZKA WUJEC AND AGATA DEPTUŁA 


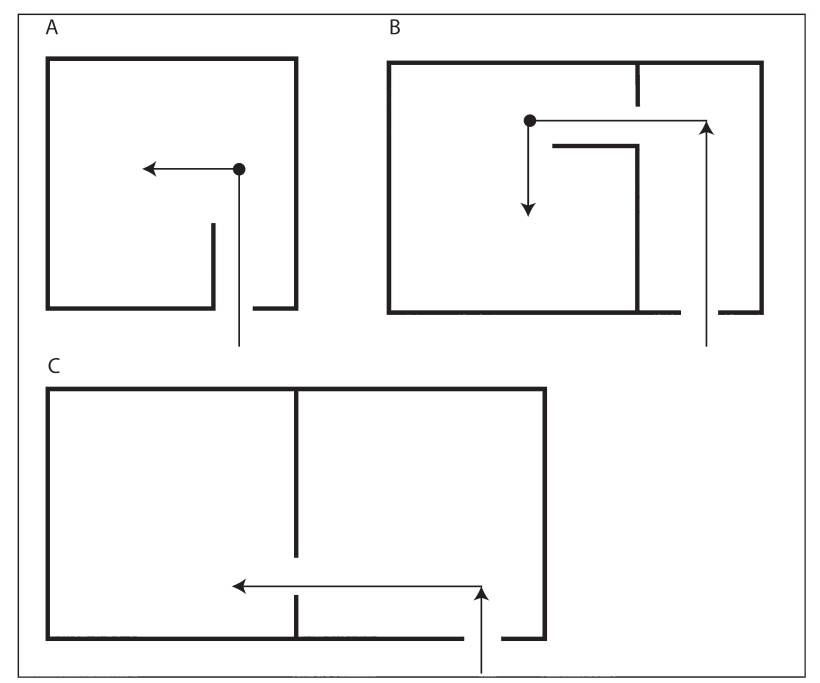

FIGURE 11 Patterns of accessibility.

DRAWING BY MACIEJ WYŻGOŁ

Access to the building was possible solely from the inner courtyard. In all cases the houses comprised two rooms located one behind the other and separated by doors (Fig. $11 b, c)$. The first room was accessible directly from the courtyard and seems to have formed a vestibule. This is clear especially in the case of U28a, where the front room was a narrow corridor without any special equipment or spaces designated for specific activity. Most probably the arrangement of the poorly preserved space U47a was similar (cf. supra). More complex is the case of the interconnected space labelled as U21a. A bench discovered there might have been used for sleeping as well as for food preparation (cf. supra). All of the above made the main rooms ( $\mathrm{U}_{2} 8 \mathrm{~b}, \mathrm{U}_{47} \mathrm{~b}$, and $\mathrm{U}_{21} \mathrm{~b}$ ) the most private spaces of the household protected against intruders in a twofold manner, not only by the vestibules but also by stub walls ensuring privacy for the inner benches.

In the subsequent phases, the organisation of space especially outside the houses is unclear due to the lack of features determining the scope of activities.

\section{Area B}

In area $\mathrm{B}$, the compound consisting of $\mathrm{U}_{15}$ and $\mathrm{U}_{37}$ (Fig. 12) was built on an earlier, uninvestigated wattle-anddaub structure, which appears to be contemporary to the earliest investigated houses of area A. It was also built abutting the walls of a long-abandoned sun-dried brick house, by then filled with aeolian sand. The house consists of two units accessible from a common courtyard, $\mathrm{U}_{4}$, located in the central part of the compound. A distinctive feature of this house is the domestic workspace U15 (Fig. 13), located within the walls of the earlier sun-dried brick house, as the dwellers of the new house made use of already standing walls. In that space, a quern emplacement

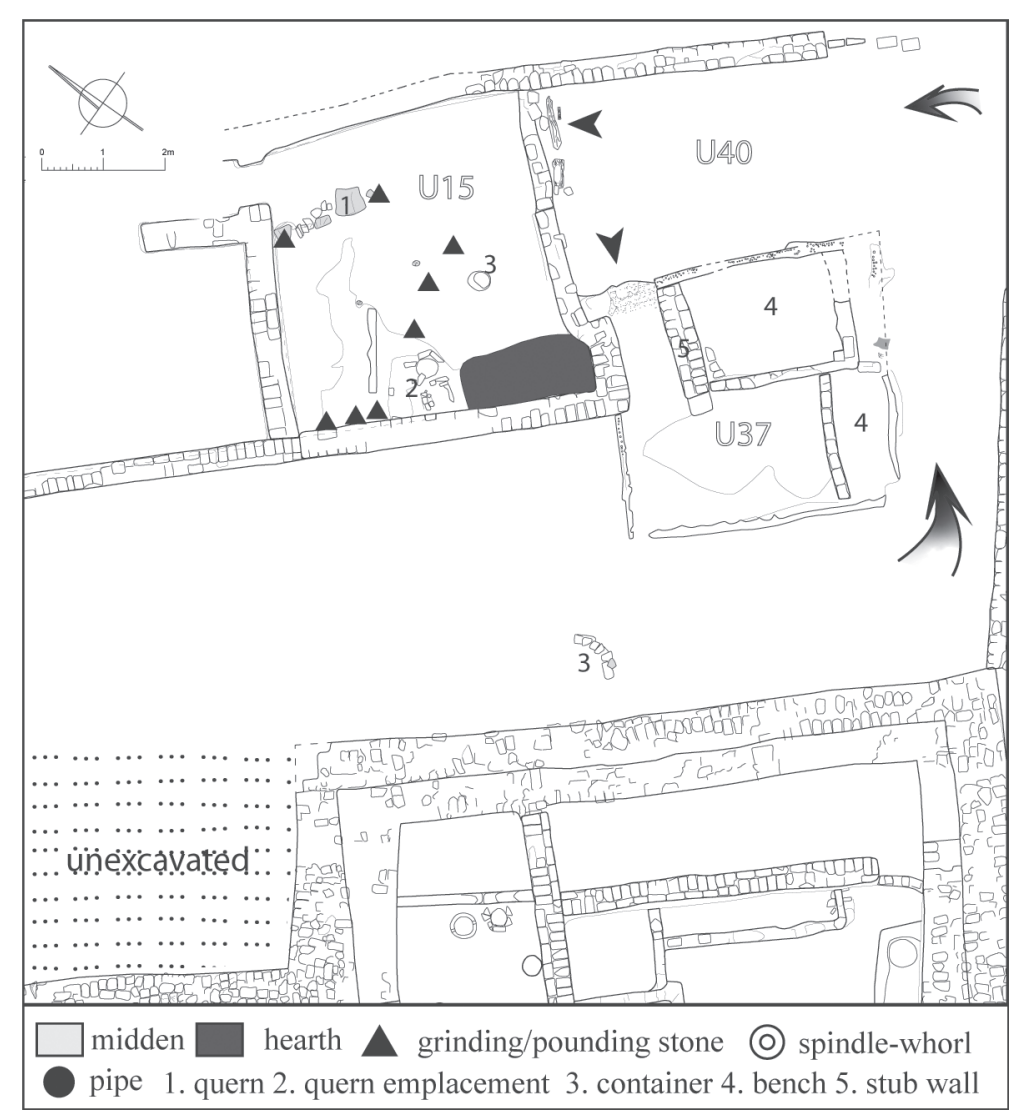

FIGURE 12

Plan of the area $B$ in the 2nd phase. DRAWING BY AGNIESZKA WUJEC AND MACIEJ WYŻGOŁ 


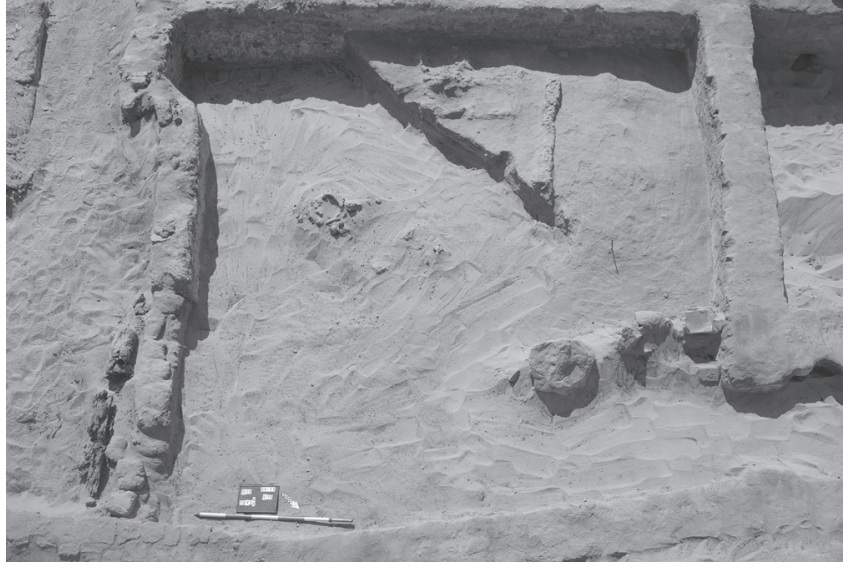

FIGURE 13 Unit 15.

PHOTOGRAPH BY MATEUSZ REKŁAJTIS

was found. A quern probably fitting the emplacement but later discarded after it broke and was put aside, was also discovered in the same area. A concentration of stone tools, presumably grinding and pounding stones, is attested in the immediate vicinity of the quern. Sorghum grains and fragments of bones of cattle and ovicaprids were also recorded, some of them burned and deposited inside a hearth.

The room $\mathrm{U}_{37}$, featuring standard furnishings, was built abutting the walls of the earlier structure inside which U15 was located. As a result, a part of the wall of U15 was incorporated into the western wall of room $U_{37}$. The house opened onto courtyard $\mathrm{U}_{40}$, where livestock was kept. A silo located outside the house, in the space between the room $\mathrm{U}_{37}$ and the town wall, might have been used by the inhabitants of this house or of house U2Oa/2ob located in area C. The relationship of house $\mathrm{U}_{37}$ with other houses in the area has not been established. The area was more likely accessed from the south-eastern complex in area A.

After the abandonment of house $\mathrm{U}_{37}$, a new house, U27, was constructed (Fig. 14). It consisted of at least one room built against the town walls. The relation to other rooms within the house is not traceable, since $\mathrm{U}_{27}$ is the only preserved part of a now lost house that has eroded off the sandy slope. Of the furnishings of room $U_{27}$, only benches of undetermined function are preserved.

\section{Interpretation}

The compound of the house $\mathrm{U}_{37}$ comprises three distinct areas. $U_{37}$, equipped with two sun-dried brick benches located behind a stub wall, appears to have been the primary dwelling space. This interpretation is corroborated by visibility analysis, which shows that the benches are not visible from the outside as a result of construction of the stub wall (Fig. 11a). The lack of any traces of activities and occupational layers suggests that this area was used

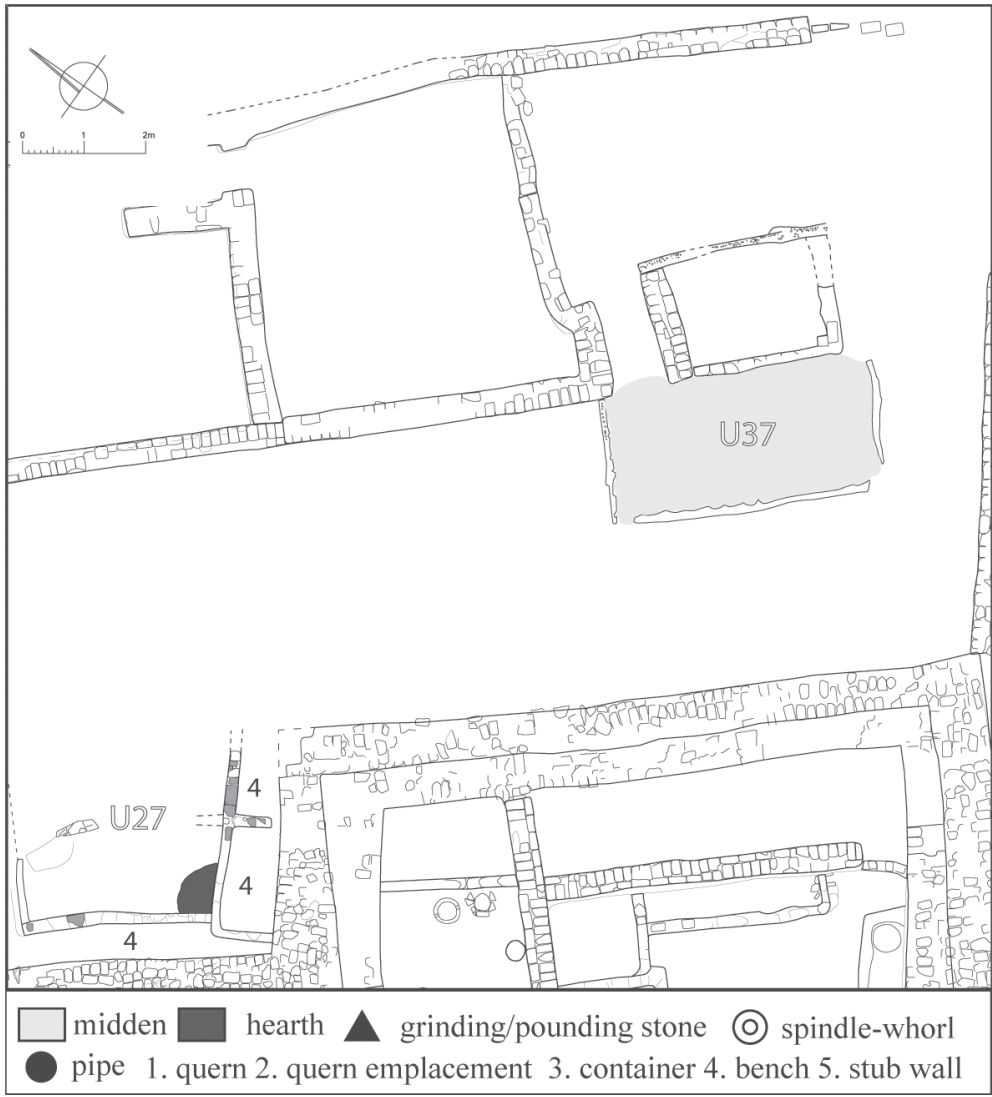

FIGURE 14

Plan of the area $B$ in the 3 rd phase.

DRAWING BY AGNIESZKA WUJEC AND MACIEJ WYŻGOE 
mostly for sleeping, but it cannot be excluded that the benches located inside served multiple purposes. Most of the activities connected with food processing were transferred to $\mathrm{U}_{15}$, which was probably a semi-open area located within the walls of an older, abandoned building. The presence of sorghum grains, a quern emplacement and discarded grinding and pounding stones supports this interpretation. Finds of containers of unbaked clay and a hearth in the corner of that space suggest that all stages of grain processing were performed in this area. Faunal remains also point to the processing of meat. The courtyard between the units certainly had the function of a passage; however, the presence of livestock is also attested by an accumulation of dung in the space between the units, as well as by the wall separating area A and area B. An additional storage space might have been located south of the house, where the silo was built.

The last phase in area B is not well recognised, as only a partially preserved house was excavated. The state of preservation of the house U27 does not allow for any conclusions about the function of space, since the benches found inside might have been multifunctional.

In the compound of house $U_{37}$, the entrances to the units comprising the compound face the inner courtyard located in the middle of the compound. The service area $\mathrm{U}_{15}$ is probably a semi-open space without doors, directly accessible from the outside. The living area is also directly connected with the courtyard; however, it is equipped with a door. A significant element is a stub wall built for privacy by the doors and shielding the interior of the room, especially the benches abutting that wall. It is also probably a part of the construction of doors. By bending the axis of the room, this type of layout protects the dwellers from intruders. There is no evidence of long-lasting presence of livestock in one specific space, given that this typically results in thick layers of tamped animal dung. Animals were kept in the compound but probably roamed freely.

House U27 does not provide any information about spatial organisation within the compound, although an analysis of the whole area sheds some light on the deposition of middens and use of abandoned houses. Construction of house $U_{27}$ follows the abandonment of houses U2Oa/2ob and $U_{37}$. The space of the houses was not reused for construction of another house, but was used to discard rubbish, as in the case of the house U2oa/2ob, or to keep livestock, as is attested in the compound of house $U_{37}$.

\section{Area C}

Concurrently, in area C house U2Oa/2ob was constructed (Fig. 15). The completely preserved room U2oa adhering to the town wall was accessible from the poorly preserved room U2ob. The relationship of the latter with other

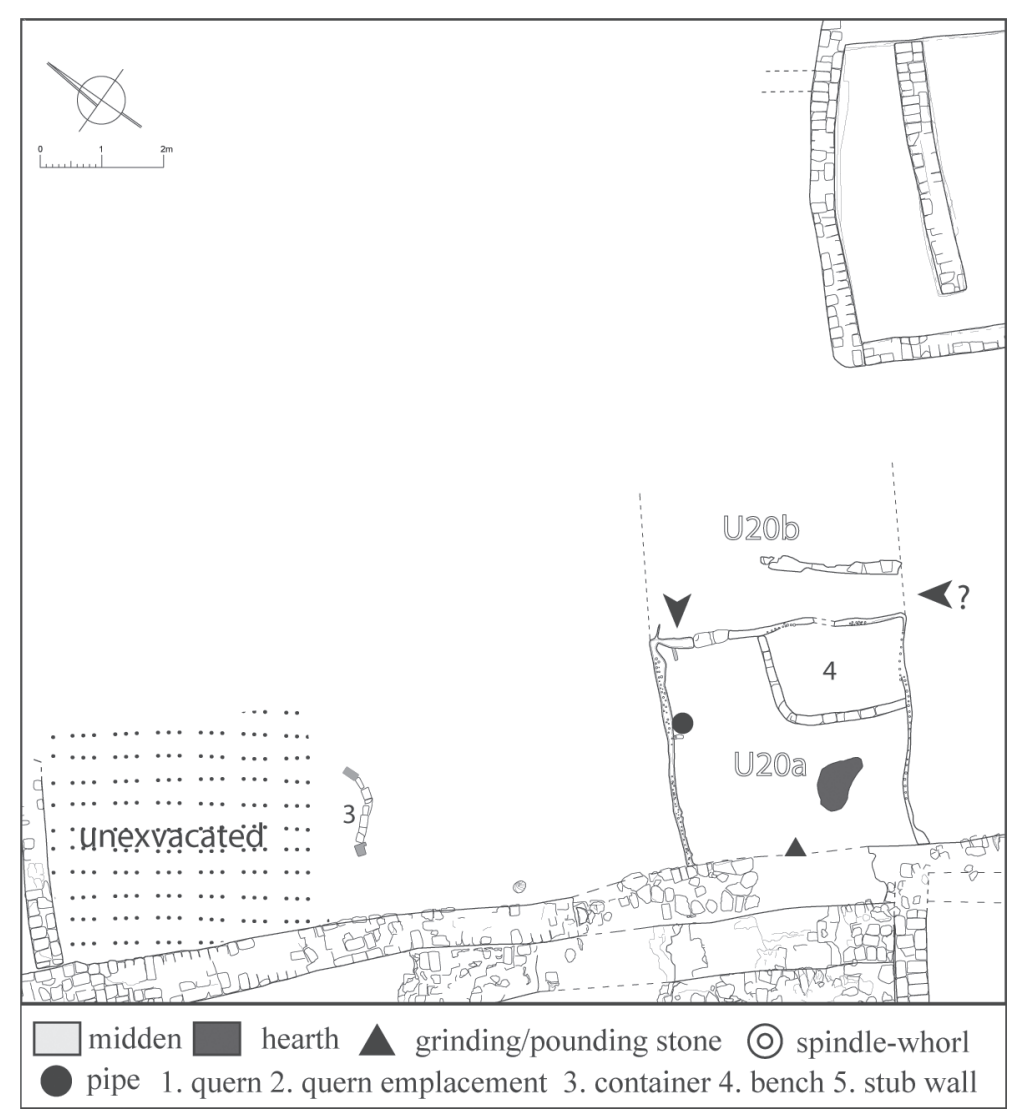

FIGURE 15

Plan of the area $\mathrm{C}$ in the 2nd phase. DRAWING BY AGNIESZKA WUJEC AND MACIEJ WYŻGOŁ 
rooms, if at all present, is not traceable, since only a bench and small fragments of outer walls are preserved. The only artefacts found within the occupational levels of house $\mathrm{U}_{20 \mathrm{a}} / 2 \mathrm{Ob}$ are a stone tool, most probably a grinding stone, and a pipe made of Nile silt (Fig. 16a). The entrance was presumably located in the eastern wall, and thus the area on that side was functionally connected with that house.
On the other hand, a connection with the area to the west cannot be excluded. A silo was located on the western side of the house and a significant number of sorghum spikelets were found in this area, as well as numerous unfinished beads made of ostrich eggshell (Fig. 16b).

After the abandonment of house U2Oa/2ob, a new house $\mathrm{U}_{3} 6$ (Fig. 17) was built in area C. It consisted of at
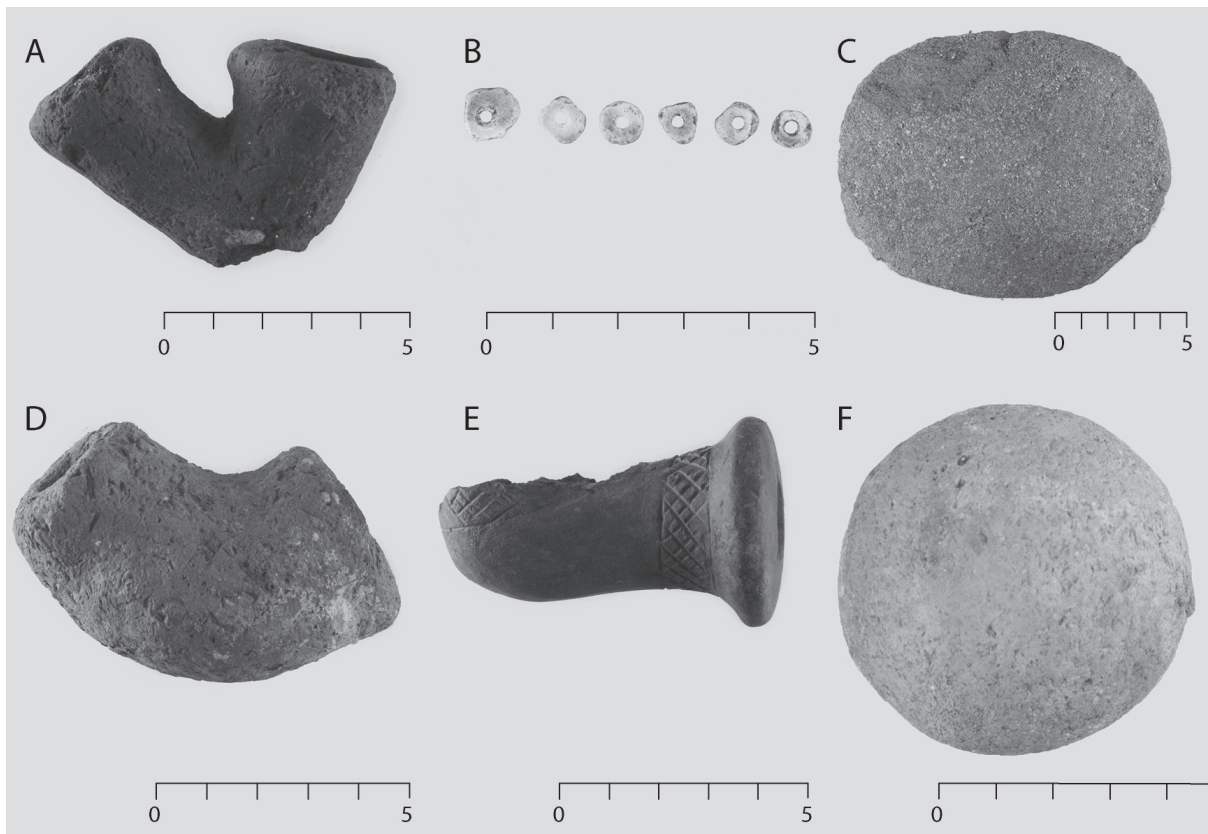

\section{F}

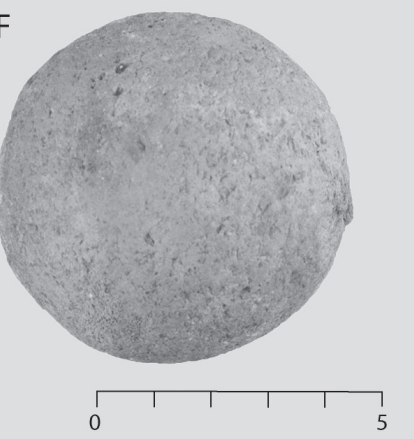

FIGURE 16

Small finds. a, d, e: local smoking pipes made of Nile silt; b: unfinished ostrich eggshell beads; c: pounding stone f: grinding stone. PHOTOGRAPHS BY MATEUSZ REKŁAJTIS

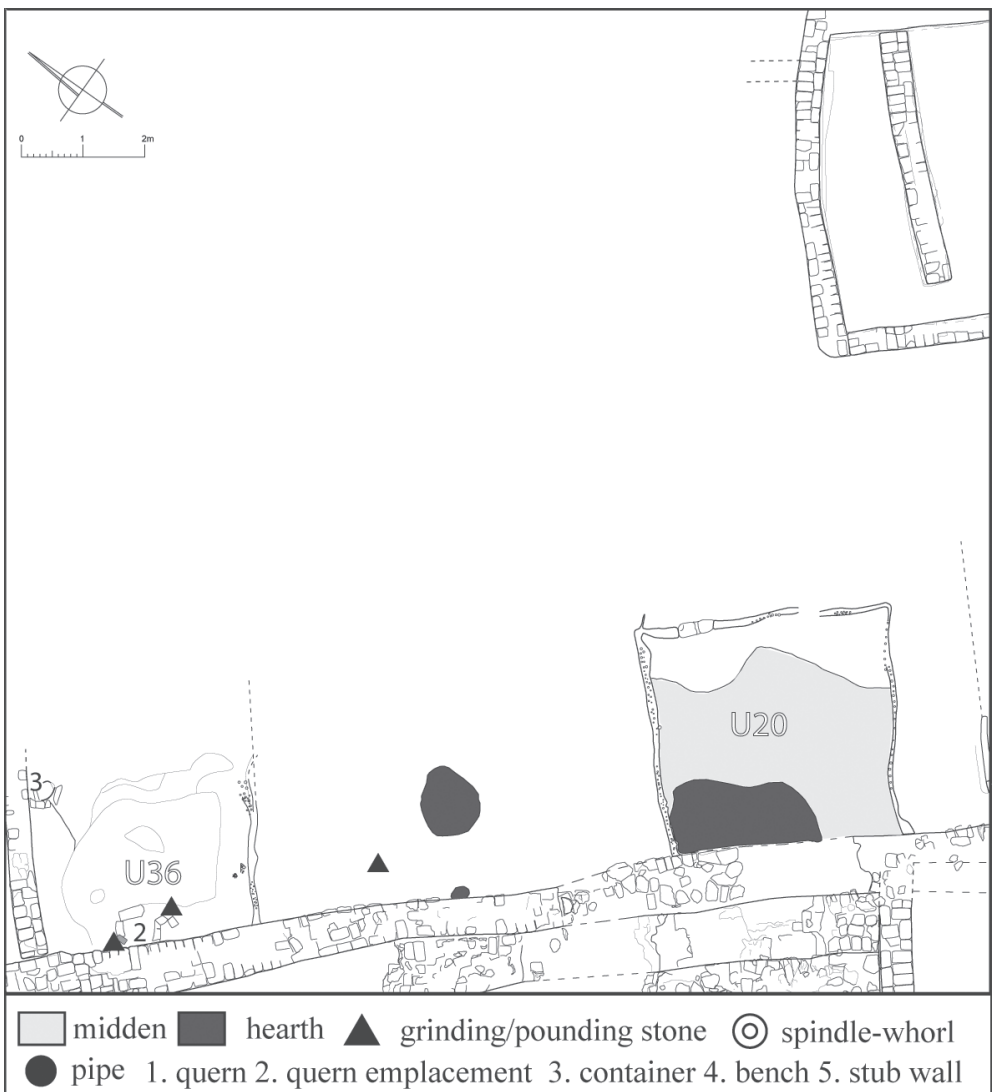

FIGURE 17

Plan of the area $C$ in the 3 rd phase.

DRAWING BY AGNIESZKA WUJEC AND MACIEJ WYŻGOE 
least one room built against the town walls. The relation to other rooms within the house is not traceable, since $\mathrm{U}_{3} 6$ is the only preserved part of a now lost house that has eroded off the sandy slope. Several stone tools were found within $\mathrm{U}_{3} 6$, as well as a number of sorghum spikelets and mangled wheat grains. Although an entrance to the house was not found, the house seems to have been functionally connected with hearths located on the eastern side of the room, containing a number of sorghum grains and burned bones of cattle and ovicaprids. ${ }^{3}$

Some activities were most probably transferred from the house to the abandoned house occupied in earlier phases. A hearth and a midden were located within the abandoned house U2Oa/2ob, which was probably associated with the adjacent houses $\mathrm{U}_{3} 6$ and $\mathrm{U}_{27}$ and used by their dwellers.

\section{Interpretation}

The function of the partially preserved house U2oa/2ob, contemporary to house $\mathrm{U}_{37}$ in area $\mathrm{B}$, is difficult to determine. The better preserved room Unoa is equipped with a hearth and a bench, however, unlike the rooms with benches in houses $\mathrm{U}_{37}$ or $\mathrm{U}_{28} \mathrm{a} / 28 \mathrm{~b}$, it lacks a stub wall. Its association with food processing is poorly attested. Also, the domestic workspace outside the house is not identified without doubts because the entrance to the house has not been found. The space east of the house was certainly associated with grain processing or storage, as an abundance of sorghum spikelets was found there. Also, the production of ostrich eggshell beads was indicated in this area by numerous finds of unfinished beads (Fig. 16b).

The last phase in this zone is not well recognised, as only partially preserved houses were excavated. U36 located in the north-westernmost part was certainly associated with grain processing and food preparation. Grains of sorghum and wheat were found in the space equipped with a quern emplacement, and also discarded grinding (Fig. 16c) and pounding stones were found in this area. The space was also equipped with a hearth and a storage vessel, which corresponds well with the finds in U15. The space of house U2oa/2ob was used by the dwellers of surrounding houses as a midden, and also possibly as a space for food processing, as is attested by a hearth located in that space.

The buildings in area $\mathrm{C}$ do not provide any information about spatial organisation within the compounds,

3 All information concerning faunal remains was provided by Salima Ikram in the unpublished report: Old Dongola. Fieldwork in 20182019 season. although an analysis of the whole area sheds some light on the deposition of middens and use of abandoned houses. The construction of house $U_{3} 6$ follows the abandonment of house $\mathrm{U}_{2} \mathrm{Oa} / 2 \mathrm{ob}$. The space of the house was not reused for construction of another house, but was used to discard rubbish, as in the case of house U2Oa/2ob. This pattern serves as confirmation for sweeping of the living spaces and suggests that the private space was kept clean, refuse was deposited outside the compound and livestock was most probably kept away from the living spaces.

\section{Discussion}

\section{Function of Space}

The use of space within the compounds clearly suggests that most activities were carried out outside the buildings. Simultaneously functioning houses $U_{37}, \mathrm{U}_{2} 8 \mathrm{a} / 28 \mathrm{~b}$ and U47a/47b, as well U21a/21b and U29 show that a separate space for food preparation was arranged away from the living unit characterised by the presence of benches and a stub wall. Houses U47a/47b and U21a/21b, as well as $U_{28}$ and $U_{29}$, use the space between them for this purpose, while $U_{15}$ in the compound of the house U 37 reused the space of an earlier, abandoned house. The sleeping area is, then, rather strictly separated from the domestic workspace. Only the evidence from house U21a/21b suggests that grain was at least kept within the living space. However, the lack of occupational layers in living/sleeping areas indicates that the spaces were regularly swept, which might hinder tracing other activities in that space. The rather limited number of spatial units in the houses, consisting of up to two rooms, suggests the multifunctionality of space. The rooms covered with roofs appear to have served mostly for sleeping, while the space outside was used for various activities, such as food preparation or bead production, with animals also kept in the space between the compounds. Other activities, for example spinning indicated by isolated finds of spindle whorls, cannot be associated with any specific area. The household space was, then, constituted by activities rather than architectural forms. Therefore, the whole space of the house was most probably used for all attested activities. The general pattern for the deposition of refuse and the keeping of livestock is not well defined. As layers of refuse were not recorded from within the compounds during their occupation, it may be assumed that middens were located outside the houses. A good example of that practice is the location of a midden within the already abandoned house U2oa/2ob. 


\section{Conceptualization of Space}

The importance of privacy is indicated mostly by the existence of doors and stub walls shielding the interior of a house from the outside and bending the axis of certain rooms (Fig. 11a, b). Also, houses consisting of interconnected rooms enable the seclusion of a rear room (Fig. 11b, c), enhancing the privacy of that area. A useful tool in the attempt to conceptualise space within the discussed compounds is a model of division of space distinguishing between the "front" and the "back" and the "communal" space versus the "family" space (Portnoy 1981). An analysis of activity areas and accessibility levels shows that the interiors of houses were private, so they can be ascribed to the category of family "back" areas reserved for activities not meant to be observed by non-family members of the community. Assuming that each compound was inhabited by a family, the courtyards and the semi-open space $\mathrm{U}_{15}$ in house $\mathrm{U}_{37}$ are generally to be understood as family "front" zones, where all everyday activities and encounters between family members occurred. Due to the fact that the discussed quarter did not include any identified public spaces, communal zones were not discerned. Likewise, zones of interaction with the outside world, such as places for entertaining guests, are difficult to distinguish.

On the basis of the archaeological record it is not possible to assess whether this seclusion of certain areas was associated with a gender division of space. Cross-cultural studies (Murdock \& Provost 1973; Martin \& Voorhies 1975; Lowell 1990; Spain 1992) and accounts of 18th- and 19th-century travellers (Burckhardt 1819; Krump 2001) point to the association of food preparation with women. Therefore, the gendered spaces may have been areas located outside rooms, in courtyards, where evidence of stages of the food preparation process is present, or in the reused space of U15. Although the compounds are oriented towards the interior, and are rather introvert, access to these spaces was fairly free. Gender divisions are generally poorly defined. The possible means of division of space vary. Nonetheless, in the case of the compound consisting of houses U21a/21b, U28a/28b and U47a/47b grouped around one courtyard it is also possible that each house was inhabited by a single family or that the houses were inhabited gender-wise.

\section{Formation Processes and Reconstruction of Activity Areas}

The processes of formation of the archaeological strata within the discussed quarter provide a framework for the interpretation of depositions and artefacts, leading to the reconstruction of activity areas. The formation processes observed in the discussed area include several cultural and non-cultural transformations (Shiffer 1976: 14-30). Their identification allows defining which of the depositions and artefact assemblages could have been directly connected with activities performed in certain locations during the life of the houses. Cultural transformations involved in site formation comprise the transfer of artefacts between systemic and archaeological contexts, mainly in the form of discarding refuse and reuse of objects. In the reconstruction of activity areas, only primary refuse (discarded at the location of use or activity) and de facto refuse (abandoned in situ in an activity area) were taken into account, as only their location may indicate activity areas, not only the simple presence of artefacts in a house. De facto refuse includes walls as well as fixed installations such as quern emplacements and storage vessels. Most of the primary refuse was observed in service areas. Stone tools, including grinding and pounding stones found in the vicinity of quern emplacements suggest that they were abandoned directly on the location of an activity. The lack of occupational layers within the houses suggests that these areas were swept and deprived of occupational layers containing artefacts associated with these spaces. Sweeping of the houses suggests that middens, which match the category of secondary refuse, were deposited away from the location of their use. Thus, accumulated depositions within, for example, the abandoned houses U2Oa/2ob and U37 should not be associated with activities performed within the houses and suggest patterns of waste disposal rather than activities.

Apart from the deposition of artefacts, their retrieval from the archaeological context resulting in their lack in the record also should be taken into consideration. Location of the discussed houses close to other functioning households led to scavenging in areas that were no longer in use. Therefore, it may by assumed that more activities were performed within the houses but it is no longer possible to trace them. Still serviceable artefacts were most probably recovered from the archaeological context at the time of abandonment; this very likely applies to storage vessels, to judge by the number of negatives of such vessels observed within the sun-dried brick houses of the same period, indicating that they were likely reclaimed after abandonment. Subsequently, the houses were also searched for reusable objects. As a result, both quern emplacements found within the houses lacked stones. The houses were also subjected to reclamation of building material. Sun-dried bricks were very often reused, as were baked bricks from much earlier Makurian buildings. Similar processes were observed in the sector of wattle-and daub houses. Circular pits dug in the layer of collapsed walls of house $\mathrm{U} 28 \mathrm{a} / 28 \mathrm{~b}$ suggest that Nile mud 
from house construction was later used for production of bricks or vessels.

Natural processes that influenced the formation of the site and caused the transfer of objects between archaeological contexts are predominantly connected with wind accumulation and erosion. The location of the discussed quarter on the northern slope of an elevated plateau caused the slope to slide, which resulted in destruction of the northern parts of houses U2oa/2ob and $U_{3} 6$. Moreover, strong wind from the north caused severe erosion of the northern side of the hill located especially in the foreground of the town walls. At the same time, large accumulations of aeolian sand occurred on the southern sides of the walls of houses.

\section{Identity of the Dwellers}

The question of group identity of the dwellers of the investigated town quarter may be tackled on the basis of the uncovered artefacts and organisation of space and their comparison with corresponding data from the sundried brick houses. An in-depth analysis would require a thorough examination of dwellings other than wattleand-daub houses, but some preliminary observations are worth discussing at this point.

It seems that the differences in building technique are not reflected in the artefact assemblages associated with the two house types. The range of pottery forms is the same in the areas within the town walls and outside $^{4}$ and it corresponds to the standard pottery assemblage of the Funj period (Wodzińska 2015). Objects of personal adornment also do not diverge from the types occurring inside the town walls. The only traceable difference in the composition of the assemblages is the exclusive occurrence of local Nile mud smoking pipes (Fig. 16a, d, e) in the district with wattle-and-daub houses, whilst imported Ottoman pipes (Danys \& Wyżgoł 2018) were frequently found in the quarter within the town walls. The layout of the houses also does not differ significantly from that of houses made of sun-dried bricks. Compounds consisting of single or double units and a courtyard occur on both sides of the town wall (Godlewski 2015: fig. 3). The furnishing of the main unit with sun-dried brick benches abutting a stub wall that shields the interior of the room from view is a further shared pattern of spatial organisation. Nonetheless, that specific element requires further discussion. Despite the wattle-and-daub construction of walls, the stub walls are

4 Information concerning pottery finds is provided by Anna Wodzińska, Katarzyna Danys and Bogusław Franczyk in the unpublished report: Old Dongola. Fieldwork in 2018-2019 season. exclusively built of sun-dried brick, as required by certain doorway construction methods in which doors are fixed to the stub wall, and also for the sake of privacy, which is achieved by shielding the benches from intruders. It is open to question whether this was a change implemented by people who originally had a different manner of house construction but adopted specific conventions of spatial organisation common for the population of Dongola. One may, however, suggest that this adaptation was introduced only after the first contacts of people inhabiting wattle-and-daub houses with the population of the town.

The absence of wattle-and-daub architecture on sites excavated in Nubia so far might lead to presumption of its external origins. The occurrence of such architecture is generally related to the sub-Saharan region and is attested widely on sites from Ghana (McIntosh 1974) to the lands of the Swahili (Wilson 1982; Fleisher \& La Violette 1999). The discovery of wattle-and-daub houses dated to the 17 th and 18 th centuries in Old Dongola might correspond with the growing contacts with the regions on the south as far as Sennar, due to the fact that these areas came under the control of the Funj Sultanate. The presence of Funj people or, more broadly, people from the south, is not attested archaeologically but may be inferred from historical events, for instance the location of colonies such as al-Dabba and Korti in the vicinity of Old Dongola (O'Fahey \& Spaulding 1974: 67). The travellers also report the presence of Funj soldiers. Another group reportedly inhabiting Old Dongola in the 17th century are merchants from the Funj Sultanate (Çelebi 1994: 151), although the reliability of this information is questionable (Peacock 2012). The lack of material evidence for the presence of inhabitants of the southern regions of the Funj Sultanate can be explained by the paucity of studies concerning the material culture of Nubia in the Funj period conducted so far. Pottery-based studies on influences from outside the Nile Valley are also still in their initial stages.

The other possible explanation of the usage of wattleand-daub might be social stratification, as building technique can be an indicator of wealth. The peripheral character of this quarter seems evident, as it is located outside the town walls, and thus far no such structures have been found within. Nevertheless, it is clear that this building technique is hardly typical of suburban architecture in Old Dongola, given the numerous examples of sun-dried brick houses in the area north of the walls (Godlewski 2015) which prove that architecture within and outside the town walls was rather homogenous. No urban centres in Nubia from this period, such as Berber or Shendi, have been examined and information provided by 
historical sources is insufficient for comparison. Data from rural sites is altogether absent. The closest analogy comes from the Swahili of the eastern African coast (Fleisher \& LaViolette 1999). The urban pattern there often shows wattle-and-daub constructions as peripheral to settlements comprising buildings made of stone. This parallel is, however, not entirely accurate, as the towns were often entirely made up of wattle-and-daub houses. The transition from wattle-and daub houses to stone buildings also often determined urban development (Wynne-Jones \& Fleisher 2014), which has not been recorded in Dongola so far. The hypothesis that the district might have been inhabited by poorer people corresponds with the lack of imported Ottoman smoking pipes and imported glazed pottery (Katarzyna Danys, pers. comm.). However, this interpretation requires the assumption that sun-dried brick was a more expensive material and could only be afforded by the wealthier inhabitants. It can be contradicted by the analysis of the houses within the town wall, where in most cases the building material is extensively supplemented by reused sun-dried brick and baked bricks from earlier abandoned structures. The procurement of this building material must have been easy and the differences in the cost of these two types of construction were rather inconsiderable. Therefore, it can be assumed that the use of the wattle-and-daub technique was an intentional choice rather than a result of economic necessity. One may suggest that the material used to build wattleand-daub houses better corresponded to the dwellers' ideas of house and comfort. The only indicator of wealth discerned so far in Old Dongola is the size of the dwellings, and while the wattle-and-daub houses seem to be relatively smaller than sun-dried brick houses, the difference is not significant.

\section{Conclusion}

The wattle-and-daub houses of Old Dongola most probably formed clusters of interrelated houses grouped around a courtyard. A house was constituted by a single unit equipped with benches, the presumed living/sleeping area was shut by a door, regularly swept, and was in several cases preceded by a vestibule. Most of the activities, of which food processing is the best attested one, were transferred outside, either to an open courtyard or to another space located away from the living area. Therefore, courtyards were communication hubs and spaces were dwellers milled, cooked, stored food and domestic equipment, and kept animals.
Inhabitants of the houses separated their domestic workspace from their living spaces and also conceptualised space with focus on privacy by favouring a specific layout of their houses, meant to protect the interior from the sight of intruders. The houses were also kept clean, as attested by patterns of refuse disposal, which was deposited away from living compounds, often in abandoned houses.

The gender division of space is hard to trace, as it is difficult to separate men from women in houses consisting of a single living unit. Such a division is, however, possible in compounds comprising several house units. Gendered spaces, mainly areas of food preparation destined for women, were not secluded and were rather easily accessible. Therefore, the seclusion of women within a family from non-kin men was certainly not expressed by architectural forms and material means.

The group identity of dwellers of the quarter under consideration the most probably differs from the rest of the town, as the choice of this particular building technique seems intentional. Whether it is a matter of origin of the group, religion, social class, ethnicity or subsistence strategy is impossible to establish at this point.

Identification of the new type of architecture outside the town walls has significant value. First of all, it has indicated that the town was more diverse than previously expected and has revealed a difference in architecture inside and outside the town walls. It has also confirmed the accounts of travellers describing Old Dongola at the turn of the 18th century. Furthermore, it has shown that the curtain wall was in use, at least for spatial division within the town, even during its latest occupational phase.

\section{Acknowledgements}

The fieldwork at Old Dongola was conducted under the auspices of the Polish Centre of Mediterranean Archaeology, University of Warsaw, within the framework of a project funded by the European Research Council (ERC Starting Grant), "UMmA. Urban Metamorphosis of a Medieval African City" headed by Dr. Artur Obłuski. The authors want to thank Dr. Dorota Dzierzbicka for reading and commenting upon a draft of this article as well as for correcting the English of this paper. The publication of this article in Open Access was financed by the University of Warsaw within the framework of the internal grant system: 'Excellence Initiative - Research University' programme - IDUB. 


\section{References}

Adams, W.Y. 2012. Islamic Archaeology in Nubia: An Introductory Survey. In: Hägg, T. (ed.) Nubian Culture Past and Present. Main papers presented at the sixth International Conference for Nubian studies in Uppsala, 11-16 August, 1986. Almqvist \& Wiksell International, Stockholm, pp. 327-361.

Blanton, R.E. 1994. Houses and Households: A Comparative Study. Plenum Press, New York.

Blier, S.P. 1987. The Anatomy of Architecture: Ontology and Metaphor in Batammaliba Architectural Expression. Cambridge University Press, Cambridge.

Bourdieu, P. 1977. Outline of a Theory of Practice. Cambridge University Press, Cambridge.

Burckhardt, J.L. 1819. Travels in Nubia. John Murray, London.

Çelebi, E. 1994. Ins Land der geheimnisvollen Func: des türkischen Weltenbummlers, Evliyā Çelebi, Reise durch Oberägyptten und den Sudan nebst der osmanischen Provinz Habeş in den Jahren 1672/73, translated by E. Prokosch. Verlag Styria, Cologne.

Crawford, O.G.S. 1951. The Fung Kingdom of Sennar. John Bellows, Gloucester.

Crown, P.L. 2000. Women and Men in the Prehispanic Southwest: Labour, Power and Prestige. School of American Research Press, Santa Fe.

Danys, K. \& Wyżgoł, M. 2018. Smoking Pipes from Old Dongola. In: Godlewski, W., Dzierzbicka, D., \& Łajtar, A. (eds.), Dongola 2015-2016. Fieldwork, conservation and site management, Polish Centre of Mediterranean Archaeology, Warsaw, pp. 189-202.

El-Bushra, S. 1971. Towns in the Sudan in the Eighteen and Early Nineteenth Centuries. Sudan Notes and Records 52, 63-70.

Elzein, I.S. 2004. Islamic Archaeology in the Sudan. Archaeopress, Oxford.

Fleisher, J. \& LaViolette, A. 1999. Elusive wattle-and-daub: Finding the hidden majority in the archaeology of the Swahili. Azania 34 (1), 87-108.

Giddens. A. 1984. The Constitution of Society: Outline of the Theory of Structuration. Polity Press, Cambridge.

Godlewski, W. 2013. Dongola - ancient Tungul. Archaeological Guide. University of Warsaw Press, Warsaw.

Godlewski, W. 2015. SWN.B.I.E: a residential quarter of the Funj period (17th century). In: Godlewski, W. \& Dzierzbicka, D. (eds.), Dongola 2012-2014. Fieldwork, conservation and site management. Polish Centre of Mediterranean Archaeology, Warsaw, pp. 223-234.

Godlewski, W. 2015a. The fortifications of Dongola and houses to the north of the Citadel. In: Godlewski, W. \& Dzierzbicka, D. (eds.), Dongola 2012-2014. Fieldwork, conservation and site management. Polish Centre of Mediterranean Archaeology, Warsaw, pp. 183-214.
Godlewski, W. 2018. Archaeological and architectural evidence of social change in $13^{\text {th-17th }}$ century Dongola. Polish Archaeology in the Mediterranean 27/1, 617-643.

Hillier, B \& Hanson, J. 1984. The Social Logic of Space. Cambridge University Press, Cambridge.

Krump, T. 2001. The Sudanese Travels of Theodoro Krump, translated by J. Spaulding, published online: https://www.kean .edu/ jspauldi/krump2four.html [10.04.2019].

Lowell, J.C. 199o. Reflections of Sex Roles in the Archaeological Record: Insights from Hopi and Zuni Ethnographic Data. In: Walde, D. \& Willows, N.D. (eds.) The Archaeology of Gender: Proceedings of the Twenty Second Annual Conference of the Archaeological Association of the University of Calgary. University of Calgary, Calgary, pp. 452-461.

MacMichael, H.A. 1922. A History of the Arabs in the Sudan: And Some Account of the People who Preceded Them and of the Tribes Inhabiting Dárfür. Cambridge University Press, London.

Martin, M.K. \& Voorhies, B. 1975. Female of the Species. Columbia University Press, New York.

Maślak, Sz. 2015. Houses of the Funj period outside the Citadel: materials and structures. In: W. Godlewski \& D. Dzierzbicka (eds.), Dongola 2012-2014. Fieldwork, conservation and site management. Polish Centre of Mediterranean Archaeology, Warsaw, pp. 215-222.

Matthews, W. \& Postgate, J.N. 1994. The Imprint of Living in Early Mesopotamian City: Questions and Answers. In: R.-M. Luff \& P. Rowly-Conwy (eds.) Whither Environmental Archaeology? Short Run Press, Exeter, pp. 171-212.

McIntosh, R.J. 1974. Archaeology and mud-wall decay in a west African village. World Archaeology6, 154-171.

Murdock, G.P. \& Provost, C. 1973. Factors in the Division of Labor by Sex: A Cross-Cultural Analysis. Ethnology 12, 203-25.

Nelson, M.N. 20o6. Handbook of Gender in Archaeology. AltaMira Press, Lanham, MD.

O'Fahley, R.S. \& Spaulding J.K. 1974. Kingdoms of the Sudan. Methuen and CO LTD, London.

Osman, A. and Edwards, D.N., The Archaeology of a Nubian Frontier: Survey on the Nile Third Cataract. Mauhaus Publishing, Leicester.

Peacock, A.C.S. 2012. The Ottomans and the Funj sultanate in the sixteenth and seventeenth centuries. Bulletin of the School of Oriental and African Studies 75, 87-111.

Poncet, Ch. J. 1709. A Voyage to Aethiopia Made in Years 1698, 1699 and 1700. Describing Particularly that Famous Empire; as Also the Kingdoms of Dongola, Sennar, Part of Egypt, \&c. With the Natural History of Those Parts. W. Lewis, London.

Portnoy, A.W. Microarchaeological View of Human Settlement Space and Function. In: Gould, A. \& Schiffer, M.B. (eds.) 
Modern Material Vulture: The Archaeology of US. Academic Press, New York, pp. 213-224.

Rainville, L. 2005. Investigating Upper Mesopotamian Household Using Micro-archaeological Techniques. Archaeopress, Oxford.

Spain, D. 1992. Gendered Spaces. University of North Carolina Press, Chapel Hill.

Vantini, G. 1975. Oriental Sources Concerning Nubia. Academy of Sciences, Heidelberg.

Vila, A. 1977. La prospection archeologique de la vallee du Nil, au sud de la Cataracte de Dal (Nubie Soudanaise). Fasc. 6, Le district d'Attab, Est et Ouest. Centre national de la recherche scientifique, Paris.

Vila, A. 1978. La prospection archéologique de la vallée du Nil, au sud de la Cataracte de Dal (Nubie Soudanaise). Fasc 10. Le District de Koyekka (rive droite), les districts de Morka et de Hanid (rive gauche), l'île de Nilwatti. Centre national de la recherche scientifique, Paris.
Wilk, R.R. \& Rathje, W.L. 1982. Household Archaeology. American Behavioral Scientist 25 (6), 617-639.

Wilson, T.H. 1982. Spatial Analysis and Settlement Patterns on the East African Coast. Paideuma 28, 201-219.

Wodzińska. A. 2015. Some Remarks on Technological and Functional Aspects of Funj-Period Pottery from Dongola In: Godlewski, W. \& Dzierzbicka, D. (eds.), Dongola 2012-2014. Fieldwork, conservation and site management. Polish Centre of Mediterranean Archaeology, Warsaw, pp. 239-258.

Wynne-Jones, S. \& Fleisher, J.B. 2014. Swahili Urban Spaces of the Eastern African Coast. In: Creekmore III, A.T. \& Fisher, K.D. (eds.) Making Ancient Cities. Space and Place in Early Urban Societies. Cambridge University Press, Cambridge, pp. 111-144.

Żurawski, B. 2014. Kings and Pilgrims. St Raphael Church II at Banganarti, Mid-Eleventh to Mid-Eighteenth Century. Neriton, Warszawa. 